\title{
JOGALKOTÁSI HATÁSVIZSGÁLAT A FIZETÉSI MEGHAGYÁSOS ELJÁRÁS ÉRTÉKHATÁRA KAPCSÁN - EGY TÁRSADALOMTUDOMÁNYI KÉRDÉS MEGVÁLASZOLÁSA ROC ANALÍZISSEL
}

https://doi.org/10.51783/ajt.2021.2.05

A jogalkotó a fizetési meghagyások elleni ellentmondások arányára hivatkozással 2018. január 1-jétől 3 millió forintra emelte a fizetési meghagyásos eljárás kötelező igénybevételének értékhatárát a peres ügyek számának csökkentése érdekében. A módositást megelözően végzett hatásvizsgálat részletei ismeretlenek, ezért kérdésként vetödik fel, hogy van-e egyáltalán kapcsolat az értékhatár és a bírósági peres ügyforgalom alakulása, valamint a fizetési meghagyással érvényesített követelés összege és az ellentmondás valószínüsége között. Ha van ilyen kapcsolat, akkor az milyen erős, és lehetséges-e a magánjogi igényeknek a mögöttük meghúzódó érdemi jogvita léte vagy hiánya szerinti csoportositása az érvényesített követelés összege alapján. A kérdések megválaszolása érdekében áttekintettem a releváns bírósági ügyforgalmi adatokat, majd leíró statisztikai és kapcsolatvizsgálati módszerekkel, valamint ROC analizis segítségével elemeztem a 2012-ben indult fizetési meghagyásos és bírósági peres eljárásokat az érvényesitett követelés összege és az eljárás kimenetele szempontjából. Azt találtam, hogy csak alig mutatható ki összefüggés az értékhatár és a peres ügyek száma között. A követelés összege pedig csak nagyon laza kapcsolatban van az érdemi jogvita létével és az eljárás kimenetelével, ezért az nem a legmegfelelőbb klasszifikátor a jogalkotó által preferált igényérvényesitési út kijelölése érdekében. Egyéb szempontok alapján azonban helyes döntés volt az értékhatár emelése, de annak még magasabb összegben, akár 6 millió forintban való meghatározása is indokolható lett volna.

\section{BEVEZETÉS}

A polgári perrendtartásról szóló 2016. évi CXXX. törvény (a továbbiakban: új Pp.) 254. §-ának (1) bekezdése 2018. január 1-jétől ${ }^{1} 1$ millió forintról 3 millió forintra emelte a kizárólag fizetési meghagyás (a továbbiakban: FMH) útján érvényesíthető pénzkövetelések összeghatárát. A módosítás célja deklaráltan a bírósági perek számának csökkentése, a járásbíróságok tehermentesítése volt. A §-hoz füzött indokolás szerint ugyanis az előterjesztő „a pertárgyérték nagyságát tekintve perré alakuló

Bíró, Fővárosi Ítélőtábla, 1027 Budapest, Fekete Sas utca 3. E-mail: drorkenyi3@gmail.com.

Az új Pp. - annak 629. §-a alapján - 2018. január 1. napján lépett hatályba. 
fizetési meghagyásos eljárások (a továbbiakban: FMH-s eljárás) arányára vonatkozó adatok alapján módosítja a kötelező fizetési meghagyásos értékhatárt, ami a járásbírósági bemeneti szinten induló ügyek mennyiségét csökkentheti”. Az indokolásban használt „kötelező” kifejezés némi magyarázatra szorul. Az új Pp. 254. §-ának (1) bekezdése ugyanis csak „a törvény eltérő rendelkezése hiányában” megszorítással teszi kötelezővé az FMH-s eljárást. Kivételt pedig már rögtön a § (3) bekezdése (ha a fél a kötelező FMH-s eljárás mellőzésével közvetlenül perben kísérelte meg igénye érvényesítését, a bíróság azonban elmulasztotta emiatt a keresetlevél visszautasítását, és az alperes perbe bocsátkozott), (4) bekezdése (perindítás előtti egyezségi kísérlet) és (5) bekezdése (ha a fél igényét a kis értékü követelések európai eljárásának bevezetéséről szóló, 2007. július 11-i 861/2007/EK Európai Parlamenti és Tanácsi rendeletben meghatározott eljárásban vagy választottbírósági eljárásban érvényesíti) is nevesít. A kötelező esetekben sem előzi meg továbbá a pert FMH kibocsátása, ha a közjegyző az erre irányuló kérelmet visszautasítja, vagy az FMH-s eljárást végzéssel megszünteti - lásd az új Pp. 255. § (2) bekezdését. A „kötelező” fogalmát praktikus okokból magam is fogom használni a továbbiakban, de ebben a kivételekkel terhelt, megszorító értelemben. ${ }^{2}$

A jogalkotásról szóló 2010. évi CXXX. törvény (a továbbiakban: Jat.) 17. §-ának (1) bekezdés első mondata alapján a jogszabály előkészítőjének a tervezett szabályozás várható következményeinek előzetes felmérése érdekében - annak feltételezett hatásaihoz igazodó részletességű - hatásvizsgálatot kell végeznie. Az előzetes hatásvizsgálat szempontrendszere Jat. 17. §-ának (2) bekezdése szerint szerteágazó, de értelemszerűen a szabályozás tárgyához igazodva célirányos. Így az FMH-s eljárás értékhatárának emelésekor nyilván a jogkereső állampolgárok adminisztrációs, ügyintézési terheire és költségeire, valamint a bírósági és közjegyzői ügyforgalomra, a költségvetési kihatásokra kellett fókuszálnia. Ez minden bizonnyal így is történt, de az új Pp. indokolásából nem derül ki, a hatásvizsgálatot milyen módszerekkel végezték, miért pont ennyi lett az új összeghatár és milyen ügyforgalmi változásokat várt tőle a jogalkotó.

A tanulmányban ismertetendő kutatás során lényegében előzetes hatásvizsgálatot végeztem - utólag. Adottságként elfogadtam azt, hogy hazánkban az uniós országok többségétől eltérően - de Ausztriához ${ }^{3}$ hasonlóan - van kötelező értékhatár az

2 A fogalom használata egyébként általános, azt széles körben használták a kodifikációs folyamat során is, így például az új Pp.-nek a polgári perjogi kodifikációról szóló 1267/2013. Korm. határozat 2. pontja alapján kidolgozott Koncepciója alapját képező tanulmánykötetben az FMH-s eljárás kötelezö értékhatárának megemelése tárgyában megjelent tanulmányban: REviczky Renáta - SZÉCsÉNYI-NAGY Kristóf: „A közjegyzői eljárások és a közvetítői tevékenység mint alternatív vitarendezési módok, valamint ezek viszonya a polgári perhez" in NÉMETH János - VARGA István (szerk.): Egy új polgári perrendtartás alapjai (Budapest: HVG-ORAC 2014) 620.; vagy az új Pp.-hez készült szakértői javaslatban: VARGA István - ÉLEss Tamás (szerk.) Szakértői javaslat az új polgári perrendtartás kodifikációjára (Budapest: HVG-ORAC 2016) 801.

3 MoLnÁR Judit: „A magyar fizetési meghagyásos eljárás az európai megoldások tükrében” $P h D$ értekezés (Miskolc, 2012) 30., http://midra.uni-miskolc.hw/document/12735/4804.pdf. A szerző által másik példaként említett Spanyolországban azonban 2011. október 31. óta minden összegszerű korlátozás nélkül opcionális az FMH-s eljárás. Lásd az 1.1.2 és 1.1.3 kérdésre adott válaszokat: e-justice.europa.ew/content_order_for_payment_procedures-296-es-en.do?init=true\#toc_1_1_1. 
FMH-val kapcsolatban, és nem vizsgáltam annak létjogosultságát alkotmányos vagy polgári jogdogmatikai szempontok alapján. Kizárólag azt elemeztem visszamenőlegesen, hogy a törvényelőkészítés idején a jogalkotó rendelkezésére álló ügyforgalmi és az érvényesített követelések összegére vonatkozó adatok alapján milyen előterjesztői javaslat lett volna megalapozható a kötelező FMH-s eljárások értékhatárának összegszerűségét illetően. A célom egyrészt az volt, hogy a matematikai statisztika modern eszközeit felhasználva vizsgáljam a módosítás indokoltságát, és meghatározzam az optimális értékhatárt. Másodlagosan - e konkrét példán keresztül - szemléltetni kívántam azt is, hogy egy jogi-társadalomtudományi probléma megoldásakor is milyen hasznosak, sőt álláspontom szerint nélkülözhetetlenek a természettudományos vagy akár a statisztikai módszerek.

\section{PROBLÉMA}

Magyarország Alaptörvényének (2011. április 25.) (a továbbiakban: Alaptörvény) 25. cikk (1) és (2) bekezdése értelmében az igazságszolgáltatás - a (7) bekezdés biztosította kivételes lehetőségtől eltekintve - hazánkban a bíróságok monopóliuma. ${ }^{4}$ Ilyen kivétel egyebek mellett az újabban a közjegyzők ${ }^{5}$ által bonyolított FMH-s eljárás. Ennek megfelelően a vagyoni jellegű polgári-, gazdasági- és munkajogi (a továbbiakban együtt: magánjogi) igények állami úton történő érvényesítésének a hatályos jogrend által biztosított két - a tanulmány szempontjából releváns - fő útja van. Az egyik az évezredes jogtörténeti gyökerekkel rendelkező - és emiatt közismertebb - polgári (gazdasági, munkajogi) per (a továbbiakban: per), a másik pedig a hazánkban 1894-ben ${ }^{6}$ német és osztrák minta alapján ${ }^{7}$ bevezetett FMH-s eljárás.

4 A 25. cikk (1) bekezdése kimondja, hogy a bíróságok igazságszolgáltatási tevékenységet látnak el. A (2) bekezdés ezt akként részletezi, hogy a bíróság dönt büntetőügyben, magánjogi jogvitában, a közigazgatási határozatok törvényességéröl, az önkormányzati rendelet más jogszabályba ütközéséről és megsemmisítéséröl, a helyi önkormányzat törvényen alapuló jogalkotási kötelezettsége elmulasztásának megállapításáról és törvényben meghatározott egyéb ügyben. A (7) bekezdés szerint azonban törvény egyes jogvitákban más szervek eljárását is lehetővé teheti.

5 A közjegyzőkről szóló 1991. évi XLI. törvény (a továbbiakban: Kjötv.) általános indokolásának 1. pontja szerint a közjegyzőség hazánkban 1874-ben létrehozott intézménye az igazságszolgáltatásnak az a része, amelynek célja a jogviták kialakulásának megelőzése, a jogi prevenció; a közjegyző a jogászi munkamegosztásban a bíró és az ügyvéd között foglal helyet. Ennek megfelelően a törvény 1 . §-ának (4) bekezdése kimondja, hogy a közjegyző a jogszabály által meghatározott hatáskörében az állam igazságszolgáltató tevékenysége részeként jogszolgáltató hatósági tevékenységet végez. Az Alkotmánybíróság is kimondta az 944/B/1994. (1995. 09. 04.) AB számú (ABH 1995, V, 734-737.) határozatában, hogy a közjegyzői tevékenység az állam igazságszolgáltató tevékenységének részét képezi.

6 A fizetési meghagyásokról szóló 1893. évi XIX. törvénycikk (a továbbiakban: Fmh. tc.) honositotta meg hazánkban. A sommás eljárásról szóló 1893. évi XVIII. törvénycikk és az Fmh. tc. életbeléptetése és az ezen törvényekre vonatkozó ügyviteli szabályok tárgyában hozott 1894. évi 745. I. M. számú rendelet I. pontja alapján lépett hatályba 1894. november 1-jén.

7 HARsÁgi Viktória: „A magyar fizetési meghagyásos eljárás fejlődéstörténetének áttekintése 1893-tól napjainkig" Iustum Aequum Salutare VIII. 2012/3-4. 223-237., www.epa.oszk. hw/02400/02445/00026/pdf/EPA02445_ias_2012_3-4_223-237.pdf. 


\subsection{A MAGÁNJOGI IGÉNYÉRVÉNYESÍTÉSI UTAK}

A magánjogi jogviták esetén a peres utat az Alaptörvény XXVIII. cikkének (1) bekezdése garantálja mindenki számára, ${ }^{8}$ és jelenleg az új Pp. szabályozza azt. A per - a ma is érvényes jogtudományi definíciója szerint - olyan kérelemre induló, törvényben szabályozott eljárás, amelyben a bíróság és az ellenérdekű felek, valamint az eljárás egyéb alanyainak tevékenysége a magánjogi jogvita végleges eldöntésére irányul. ${ }^{9}$ A tanulmány szempontjából legfontosabb jellemzője, hogy a felek között általában érdemi jogvita van, és nemcsak vagyoni, hanem személyi jellegű igények is tárgyát képezhetik (pl. házassági perek, személyállapoti perek). A felperesnek a keresetlevélen - a fő szabály szerint - a követelés 6\%-ának megfelelő kereseti illetéket ${ }^{10}$ kell lerónia. A bíróság általában ítélette ${ }^{11}$ dönti el a jogvitát, ami alapján - jogerőre emelkedése ${ }^{12}$ esetén - bírósági végrehajtás elrendeléséne ${ }^{13}$ van helye.

Az FMH-s eljárásról szóló, jelenleg hatályos 2009. évi L. törvény (a továbbiakban: Fmhtv.) 1. §-ának (1) bekezdése szerint az FMH-s eljárás a közjegyző hatáskörébe tartozó, a pénzkövetelések érvényesítésére szolgáló egyszerűsített polgári nemperes eljárás, amelyre - ha a törvény eltérően nem rendelkezik - az új Pp. szabályait a polgári nemperes eljárás sajátosságaiból eredő eltérésekkel kell alkalmazni. A (2) bekezdés értelmében az eljárásban a közjegyző a Magyar Országos Közjegyzői Kamara (a továbbiakban: MOKK) interneten elérhető, országosan egységes számítástechnikai rendszerének használatával, gépi adatfeldolgozással jár el.

A jogintézmény legfőbb célja, hogy az előreláthatólag nem vitatott, meghatározott pénzösszeg megfizetésére irányuló követeléseket peren kívül gyorsan, költségkímélő módon intézzék el ${ }^{14}$. Az eljárás lényege, hogy az, akinek pénzkövetelése van

8 Ez kimondja, hogy mindenkinek joga van ahhoz, hogy jogait és kötelezettségeit törvény által felállított, független és pártatlan bíróság perben, tisztességes és nyilvános tárgyaláson, észszerủ határidőn belül bírálja el.

9 Kengyel Miklós: Magyar polgári eljárásjog (Budapest: Osiris 2008) 34.

${ }^{10}$ Az illetékekről szóló 1990. évi XCIII. törvény (a továbbiakban: Itv.) 42. §-ának (1) bekezdés a) pontja kimondja, hogy peres eljárásban az illeték mértéke a 39-41. §-ban meghatározott illetékalap után - ha az Itv. másként nem rendelkezik - 6\%, de legalább 15000 forint, legfeljebb 1,5 millió forint.

${ }^{11}$ Az új Pp. 265. §-ának b) pontja alapján a bíróság a per érdemben fő szabály szerint ítélettel határoz, de az a) pont értelmében bírósági meghagyást is kibocsáthat, vagy a 239. § (1) bekezdésének megfelelően a felek érdemi egyezségét is jóváhagyhatja végzéssel.

${ }^{12}$ Az új Pp. 258. §-ának (3) bekezdése értelmében a fellebbezéssel megtámadható határozat, így az ítélet a fellebbezési határidő leteltét követő naptól kezdve jogerős, ha az arra jogosultak egyike sem nyújtott be fellebbezést, vagy a benyújtott valamennyi fellebbezést a bíróság jogerősen visszautasította.

13 A bírósági végrehajtásról szóló 1994. évi LIII. törvény 13. §-ának (1) bekezdése és 15. §-ának (1) bekezdés a) pontja szerint a jogerős ítélet alapján a 10. § a) pontjában írt végrehajtási lapot lehet kiállítani, és megindulhat a végrehajtási eljárás.

14 SzÉcsÉNYI-NAGY Kristóf: Nagykommentár a fizetési meghagyásos eljárásról szóló törvényhez (Budapest: CompLex 2012) 34. 
(a továbbiakban: jogosult), fő szabályként elektronikus úton, formanyomtatványon ${ }^{15}$ kérelmet nyújt be az FMH kibocsátása iránt a közjegyzőhöz. Az eljárásért általában a követelés 3\%-ának megfelelő eljárási díjat ${ }^{16}$ kell megfizetni. Ha a kérelem alakilag megfelelő, akkor a közjegyző rövid határidőn belül, a kötelezett meghallgatása és bizonyítás felvétele nélkül kibocsátja ${ }^{17}$ az FMH-t.

A kibocsátott FMH a kérelemben megjelölt személyhez (a továbbiakban: kötelezett) intézett felhívás (meghagyás), hogy a követelt összeget tizenöt napon belül fizesse meg a jogosultnak. ${ }^{18} \mathrm{~A}$ kibocsátott FMH lényegében az eljárás során az ügy érdemében hozott határozat, mely a kötelezettre nézve pénzbeli marasztalást tartalmaz. ${ }^{19}$ Vagy másképpen: egyoldalú kérelemre a kötelezetthez intézett felhívás a jogosult követelésének meghatározott határidőn belül, végrehajtás terhe mellett történő megfizetésre. ${ }^{20} \mathrm{Ha}$ a kötelezett nem vitatja a követelést, akkor az FMH a bírósági ítélethez hasonlóan jogerőre emelkedik, ${ }^{21}$ és bírósági végrehajtás rendelhető el. ${ }^{22}$ Ezek azok az esetek, amikor valójában nincs érdemi jogvita a felek között. Éppen a végrehajthatóság az FMH azon tulajdonsága, amely az FMH-s eljárást a peres eljárás vonzó alternatívájává teszi. Ha azonban a kötelezett vitatja a követelést, és a megadott határidőn belül ellentmondással él, ${ }^{23}$ akkor az eljárás perré alakul. ${ }^{24} \mathrm{~A}$ közjegyző ilyenkor felhívja a jogosultat a keresetlevél előterjesztésére, ${ }^{25}$ és

${ }^{15}$ Az Fmhtv. 19. §-a szerint az FMH kibocsátása iránti kérelmet írásban, az erre rendszeresített ürlapon vagy szóban kell elöterjeszteni.

${ }^{16}$ Az Fmhtv. 42. §-ának (1) bekezdése kimondja, hogy az FMH kibocsátása iránti kérelem előterjesztéséért a MOKK részére - a MOKK rendszere üzemeltetési költségeinek, valamint a közjegyzők munkadíjának és költségeinek fedezése érdekében - a 44. § (1 bekezdése szerint a pénzkövetelés összege után a 45. § (1) bekezdésének a) pontja alapján 3\%, de legalább 8000 forint és legfeljebb pedig 300000 forint eljárási díjat kell fizetni.

${ }_{17} \mathrm{Az}$ Fmhtv. 26. §-ának (1) bekezdése értelmében, ha a fizetési meghagyás kibocsátása iránti kérelem visszautasításának nincs helye, és ha nem kell a felet a hiányok pótlására felhívni, vagy a fél a hiánypótlási kötelezettségének eleget tett, a közjegyzö az ellenfél meghallgatása (nyilatkoztatása) nélkül köteles a fizetési meghagyást a kérelem beérkezésétől számított tizenöt napon belül - elektronikus úton beadott kérelem esetén három munkanapon belül - papír alapon kibocsátani.

${ }^{18} \mathrm{Az}$ Fmhtv. 27. §-ának (1) bekezdés c) pontja kimondja, hogy az FMH-nak tartalmaznia kell azt a meghagyást, hogy a kötelezett a követelésnek a meghagyás kézbesítésétől számított tizenöt nap alatt tegyen eleget.

${ }^{19}$ Az FMH tehát az Fmh. tc. indokolásának rendkívül frappáns és máig érvényes megfogalmazása szerint „nem egyéb, mint anticipált makacssági ítélet”.

${ }^{20}$ Lugosi József: Kézikönyv a fizetési meghagyásos eljárásról (Budapest: HVG-Orac 2010) 21.

${ }^{21} \mathrm{Az}$ Fmhtv. 36. §-ának (1) bekezdése kimondja, hogy amennyiben a fizetési meghagyást nem támadták meg határidőn belül ellentmondással, annak ugyanolyan hatálya van, mint a jogerős ítéletnek. A (2) bekezdés szerint pedig ebben az esetben a közjegyző a meghagyás kiadmányát jogerösítési záradékkal látja el, és így kézbesítteti a jogosultnak.

${ }^{22}$ Az Fmhtv. 52. §-ának (2) bekezdése alapján az FMH-t kibocsátó közjegyző, annak jogerőre emelkedése esetén, kérelemre a $§(4)$ bekezdése szerint végrehajtási lappal rendelheti el a végrehajtást.

${ }^{23} \mathrm{Az}$ Fmhtv. 28. §-ának (1) bekezdése szerint az FMH ellen a kötelezett annak kézbesítésétől számított tizenöt napon belül a közjegyzőnél ellentmondással élhet.

${ }^{24} \mathrm{Az}$ Fmhtv. 37. §-ának (1) bekezdése úgy rendelkezik, hogy a kellő időben előterjesztett ellentmondás folytán az FMH-s eljárás - az ellentmondással érintett részben - perré alakul át.

${ }^{25}$ Az Fmhtv. 37. §-ának (3) bekezdés a) pontja. 
a megfizetett eljárási díj összegének a peres eljárás illetékére való kiegészítésére, ${ }^{26}$ az iratokat pedig megküldi a perre illetékes bíróságnak. ${ }^{27}$

A rövid ismertetés alapján is érzékelhetők a két jogintézmény közötti alapvető különbségek. A per időigényes, akár évekig eltarthat, a felek személyes vagy képviselőn keresztüli aktív részvételét, de legalábbis közremüködését igényli, és (illeték) költsége a követelés 6\%-a. A perek intézésével kapcsolatos állami költségek is jelentősek. A Magyarország 2019. évi központi költségvetéséről szóló 2018. évi L. törvény 1. számú mellékletének VI. fejezete szerint a bíróságok előző évi működési költségvetési föösszege 113,8344 milliárd forint volt. A bírák hozzávetőleg kétharmad része foglalkozik a magánjogi jogviták elbírálásával (a többiek büntető ügyeket intéznek), tehát úgy kalkulálhatunk, hogy a magánjogi igények bírósági úton történő érvényesítése hozzávetőleg 76 milliárd forint költségvetési forrást igényelt. ${ }^{28} \mathrm{~A}$ bíróságok 2019-ben összesen 144750 elsőfokú magánjogi pert ${ }^{29}$ fejeztek be. Egy-egy magánjogi per bírósági elbírálásának állami költsége tehát - minden jogorvoslati lehetőséget figyelembe véve - 525043 forint (76 milliárd forint/144 750 ügy) volt.

Ezzel szemben az FMH-s eljárásban optimális esetben - a postai kézbesítés időigényét nem számítva - $30(15+15)$, de akár $18(3+15)$ napon belül jogerős, végrehajtható határozathoz juthat a jogosult, tehát az eljárás nagyon rövid. Nem igényel a jogosult részéről személyes közremüködést, tehát nagyon egyszerű. Költsége csak a követelés 3\%-a, tehát olcsóbb a jogosult számára. Az FMH-s eljárás az állami költségvetést sem terheli, mert a közjegyzői rendszert nem az állam tartja fenn. A közjegyzők - bár az igazságszolgáltatási szervezet részét képezik - nem állami alkalmazottak, hanem szellemi szabadfoglalkozásúak, ${ }^{30}$ akik tevékenységüket önállóan, az eljárást kezdeményező fél vagy érdekelt által fizetett munkadíj és költségtérítés fejében végzik. ${ }^{31}$

${ }^{26}$ Az Fmhtv. 37. §-ának (3) bekezdés b) pontja. A közjegyző felhívásában meghatározott kiegészítő eljárási illeték összegszerűségét az Itv. 42. §-ának (2) bekezdése határozza meg akként, hogy amennyiben az FMH-s eljárás perré alakul, akkor a 42. § (1) bekezdés a) pontja szerinti - a peres eljárások esetén irányadó mértékű - illetéket kell fizetni, de abba az FMH-s eljárásért megfizetett díj - esetleges kedvezményekkel csökkentett - összegét be kell számítani.

27 Az Fmhtv. 38. §-ának (1) bekezdése.

28 A tényleges szám ettől némileg biztosan alacsonyabb, mert a bíróságok nemcsak magánjogi és büntető peres ügyeket intéznek, hanem például nemperes magánjogi (cégügyek, társadalmi szervezetek nyilvántartási ügyei) és büntető nemperes ügyeket, szabálysértési ügyeket és közigazgatási pereket is. A bíróságok költségvetésének egy része tehát ezekre fordítódik, így a magánjogi peres ügyek elbírálása valójában nem emészti fel a teljes költségvetés kétharmad részét. Pontosabb becslést a személyi állomány feladatainak sokrétűsége miatt nehéz mondani, de a mondott szám jó közelítésnek tekinthető.

${ }^{29}$ Helyi szinten 120373 polgári, 6885 gazdasági, 5483 munkaügyi, törvényszéki szinten pedig 7481 polgári és 4528 gazdasági pert. Adatok forrása: www.birosag.hw/ugyforgalmi-adatok/birosagiugyforgalom-2019-eves-adatai.

${ }^{30}$ KöBlös Adél: „A közjegyzők és az Alaptörvény” Magyar Jog 2014. 129-136.

31 A Kjötv. 6. §-a és jelenleg a közjegyzői díjszabásról szóló 22/2018. (VIII. 23.) IM rendelet 1. §-a. 


\subsection{VÁLASZTÁS AZ IGÉNYÉRVÉNYESÍTÉSI UTAK KÖZÖTT}

A per vagy FMH kérdése tekintetében tehát a jogosult (és az állam) választása első pillantásra egyértelműnek tủnik. De a helyzet nem ilyen egyszerű. Egyrészt nem biztos, hogy az FMH végleges megoldás és általa feltétlenül „megspórolható” a per költség- és időszükséglete, mert a kötelezett ellentmondással élhet. Azaz, ha a felek között valódi jogvita van, akkor az FMH-s eljárás „zsákutca”. Ez ugyan többlet költséggel nem jár - legalábbis a jogosult számára - ahhoz képest, mintha rögtön pert indított volna, mert a fentiek szerint az FMH eljárási díja beleszámít a peres eljárás illetékébe, de az FMH kezdeményezése mégiscsak többletmunkát és időveszteséget jelent. A jogosultnak tehát a döntése meghozatalakor számításba kell vennie az ellentmondás kockázatát és annak valószínűségét is. Ha ez utóbbi magas, akkor akár felesleges is lehet FMH kibocsátását kérnie. Lényegében azt kell megpróbálnia megbecsülni, hogy mekkora a tényleges jogvita kialakulásának esélye az ügyben.

Másrészt a per és az FMH-s eljárás valójában nem is mindig alternatívái egymásnak. Nem minden esetben lehet ugyanis FMH kibocsátását kérni, és pert sem lehet minden esetben indítani. Az igényérvényesítés útjai közötti választás lehetősége szempontjából egyik nagyon fontos tényező a jogvita tárgya. Az FMH kibocsátása a fentiek szerint jelenleg ${ }^{32}$ kizárólag pénzkövetelések esetén kérhető, így egyéb igények (pl. bizonyos dolog kiadása, valaminek a megállapítása, házasság felbontása stb.) esetén eleve csak a perindítás marad. A másik - és a tanulmány szempontjából kiemelten fontos - tényező pedig a követelés összege. Egyrészt ugyanis az új Pp. 254. §-ának (1) és az Fmhtv. 3. §-ának (2) 33 bekezdése szerint a pénz fizetésére irányuló olyan lejárt követelés, amelynek összege a 3 millió forintot nem haladja meg - a már említett kivételekkel - csak FMH-s eljárásban érvényesíthető. Ilyen esetben tehát a perindítás kizárt. Másrészt ugyanakkor az Fmhtv. 3. §-ának (3) bekezdése azt is kimondja, hogy nem érvényesíthető FMH-s eljárás útján az a pénzkövetelés, amelynek összege a 30 millió forintot meghaladja.

\subsection{AZ FMH-S ELJÁRÁS KORLÁTAI}

A vizsgálat tárgyát képző - kizárólag pénz fizetésére irányuló - követelések esetén tehát az FMH kötelező igénybevételének 3 millió forintos és az FMH alkalmazását kizáró 30 millió forintos értékhatárnak van jelentősége. Egymáshoz viszonyított összegük alapján a továbbiakban az előbbit nevezzük az FMH alsó, az utóbbit pedig a felső korlátjának. A jelenleg hatályos szabályozás tehát kettős korlátot alkalmaz.

32 A jogintézményt korábban szabályozó polgári perrendtartásról szóló 1952. évi III. törvény (a továbbiakban. Pp.) 313. §-ának (1) bekezdése 2012. június 30-ig lehetővé tette az FMH kibocsátását akkor is, ha a követelés ingó dolog kiadására irányult, a jogintézményt meghonosító Fmh tc. 1. §-a pedig eredetileg értékpapírok iránti követelések esetén is.

${ }^{33} \mathrm{Az}$ Fmhtv. 3. § (2) bekezdésének szövegét az új Pp. hatálybalépésével összefüggő egyes törvények módosításáról szóló 2017. évi CXXX. törvény (a továbbiakban: új Ppé.) 74. §-ának (2) bekezdése állapította meg. 
Ennek azonban nem feltétlenül kellene így lennie. Szabályozható az FMH-s eljárás úgy is, hogy vagy csak alsó, vagy csak felső korlát van, illetőleg egyáltalán nincs az érvényesített követelés összegével kapcsolatos korlát. Ehhez képest tehát elméletileg négyféle szabályozási modell definiálható. A hazai szabályozástörténetben sem mindig a jelenlegi szabályozási modellt alkalmazta a jogalkotó. Volt olyan időszak (1953-1973 és 1993-2012 között) amikor csak alsó és volt, amikor (1894-1931 között) csak felső korlát volt, 1931-1953, illetve 1973-1993 között pedig a jelenlegivel azonos módon kettős korlátot alkalmaztak. Így tehát 1894 óta öt ízben (1931ben, 1953-ban, 1973-ban, 1993-ban és 2012-ben) történt modellváltás. A szabályozási modellek váltakozása mellett még gyakrabban - az FMH alig több mint százéves hazai történetében huszonhat (!) alkalommal - került sor a korlátok összegének valamilyen módosítására. ${ }^{34}$

A korlátok normaszövegekből kiolvasható összegszerü változásai azonban - tényleges hatásaikat illetően - azért értelmezhetők nehezen, mert az FMH jogintézményének meghonosítása óta eltelt időben három különféle fizetőeszköz volt érvényben: 1894-1926 között a - még az Osztrák-Magyar Monarchiából örökölt - korona, 1927-1948 kötött a pengö ${ }^{35}$ és 1948 óta a forint. ${ }^{36}$ Továbbá rövid, de rendkívüli mértékủ pénzromlást eredményező inflációs periódusok (a két világháború alatt, illetőleg után) is tarkították a jogintézmény létezésének időszakát.

Erre tekintettel az alkalmazott szabályrendszer - szabályozási modell szerinti reális besorolása és értékelése érdekében elengedhetetlen volt a korlátok mindenkori fizetőeszközben kifejezett értékeinek jelenértékre (2020. évi forint) való átszámítása. Ennek alapján az állapítható meg, hogy a látszattal ellentétben 1953 óta - és jelenleg is - valójában csak alsó korlát van. ${ }^{37}$ A tanulmány - az összegszerüség ismételt változásának apropóján - a továbbiakban ezzel a korláttal foglalkozik.

Eddigi vizsgálataim alapján az alsó korlát jelenértéke több mint egy évszázadon keresztül lényegében változatlan volt. Bevezetésétől 2008-ig - 2020. évi forintban számítva - néhány tízezer és 500000 forint között ingadozott, 1931-2008 közötti átlaga 225623 volt. Ebben a hetvenhét éves időszakban semmilyen hosszabb távú, trendszerű változás nem mutatható ki. Azonban a Pp. és egyes kapcsolódó törvények módositásáról szóló 2008. évi XXX. törvény (a továbbiakban: X. Ppn.) 45. §-a alapján az alsó korlát értéke 2009. január 1-jén ${ }^{38}$ az 1998. január 1. óta érvényben

34 A szabályozási modellek jogtörténeti megközelítésű áttekintését illetően lásd: ÖRKÉNYI László: „A fizetési meghagyásos eljárás hazai szabályozási modelljei és azok időbeli változásai az értékhatárral kapcsolatos szabályok alapján” Magyar Jog 2020. 433-443.

${ }^{35}$ A pengőérték megállapításáról és az ezzel összefüggő rendelkezésekről szóló 1925. évi XXXV. törvénycikk 1927. január 1 -jén vezette be a pengőt.

${ }^{36}$ A pengő hiperinflációját lezárandó a forintérték megállapításáról és az ezzel összefüggő rendelkezésekről szóló 9.000/1946. M. E. számú rendelet 1. §-ának (1) bekezdése, valamint a forintérték pénzlábának és ebből adódó aranyértékének megállapításáról szóló 8.700/1946. M. E. számú rendelet rendelkezett a forint 1946. augusztus 1. napjával történő bevezetéséről.

37 Az FMH korlátainak jelenértékre számításáról részletesebben lásd: ÖRKÉNYI László: „A fizetési meghagyásos eljáráshoz kapcsolódó értékhatárok változása az árszínvonal változásának tükrében” Magyar Jog 2020. 599-609.

38 A törvény 63. §-ának (1) bekezdése alapján ekkor lépett hatályba. 
volt 200000 forintról $^{39}$ ötszörösére, 1 millió forintra emelkedett. Ez még jelenértéken - 276000 forint, illetve 1320000 forint - számolva is egyértelmű, az infláció akkori üteme által indokolt mértéket jelentősen meghaladó emelkedés. Végül pedig ezt a már jelentősen megemelt alsó korlátot emelte tovább 2018. január 1-jén - alig kilenc év elteltével - az új Pp. - (hatás)vizsgálat tárgyát képező - említett 254. §-a - ezúttal háromszorosára. Ezzel tehát az FMH alsó korlátja végleg kiszakadt a korábban hosszú időn keresztül következetesen megtartott néhány százezres sávból, és egy nagyságrenddel magasabbra, a néhány milliós tartományba emelkedett. Az előterjesztő az új Pp. 254. §-ához füzött már idézett indokolásában lakonikus tömörséggel csak annyit rögzített ezzel kapcsolatban, hogy ezáltal csökkenteni reméli a „járásbírósági ${ }^{40}$ bemeneti szinten induló ügyek mennyiségét”.

A jogalkotó tehát azért módosította az FMH alsó értékhatárát, mert azt gondolta, hogy ezáltal érdemben képes befolyásolni a bíróságokra érkező peres ügyek számát. Minden bizonnyal annak érdekében, hogy ezen keresztül csökkentse a bíróságok munkaterhét és így a peres eljárások időtartamát. Ez logikusnak tűnik, mert minél magasabb az FMH alsó korlátjának értéke, a követelések annál nagyobb hányadát kénytelenek a jogosultak FMH útján érvényesíteni, és annál kevesebb per indul a bíróságokon. A jogintézmény hazai fejlődése alapján látható, hogy a jogalkotó hoszszú időn keresztül csak az FMH-t érintő szabályozási tárgyként tekintett az alsó korlátra és az értékállandóság megőrzésére törekedett. Az utóbbi évtizedben azonban szakított ezzel, és egyértelműen és deklaráltan jogpolitikai eszközként kezdte használni annak értékét az ügyérkezés FMH irányába terelése érdekében. Így tehát az FMH alsó korlátja ma már nemcsak egy - kizárólag az FMH jogintézményére vonatkozó - sarkalatos jellemző, hanem egyúttal a jogpolitika - hatékonynak vélt - eszköze az állami úton való magánjogi igényérvényesítés kívánatosnak tartott irányba terelésére. Ezzel pedig elérkeztünk a tanulmány központi kérdéseihez.

\section{KÉRDÉSEK}

Az első - ügyforgalommal kapcsolatos - kérdés az, hogy valójában milyen összefüggés van az alsó korlát értéke és a perek száma között. Megalapozott-e az a deklarált jogalkotói várakozás, hogy az FMH alsó korlátjának emelése csökkenti a perek számát? Valóban alkalmas eszköz-e az FMH alsó korlátjának mozgatása az eljárások meghatározott irányba terelésére? Ha ugyanis az FMH ellen a kötelezett ellentmondással él, akkor az eljárás perré alakul. Ha pedig ez akár egyetlen, a megemelt

${ }^{39}$ Megállapította a Pp. módositásáról szóló 1997. évi LXXII. törvény (a továbbiakban: VII. Ppn.) 33. §-ának (2) bekezdése, hatályba lépett a törvény 34. §-ának (2) bekezdése alapján.

${ }^{40}$ A bíróságok szervezetéről és igazgatásáról szóló 2011. évi CLXI. törvény hatályba lépését, azaz 2012. január 1. napját megelözően az azonos címủ 1997. évi LXVI. törvény 16. §-a alapján a bírósági szervezetet a helyi szintű városi és kerületi bíróságok, a munkaügyi bíróságok, a megyei bíróságok, az itélőtáblák és a Legfelsőbb Bíróság (a továbbiakban: LB) alkották. Az új törvény 16. §-a - részben a szervezeti átalakítások miatt - módosította a különböző szintű szervezeti egységek nevét: a városi bíróságokból járásbíróságok, a munkaügyi bíróságokból közigazgatási és munkaügyi bíróságok, a megyei bíróságokból törvényszékek lettek, az LB neve pedig Kúriára változott. 
alsó korlátra tekintettel immár kényszerűen FMH útján érvényesített követelés esetében is előfordul, akkor biztosan nem csökken annyival a perek száma, mint amenynyivel emelkedik az FMH kibocsátása iránti kérelmeké. Márpedig ez valószínủ. Az FMH-k alsó korlát emelésének hatására megemelkedő száma tehát nem jár feltétlenül a perek számának ugyanekkora csökkentésével.

A jogalkotó az új Pp. 254. §-ához füzött indokolásában utalt arra, hogy a különböző pertárgy értékű fizetési meghagyásos eljárások perré alakulási arányára vonatkozó adatok alapján módosítja az értékhatárt. A részletes adatokkal azonban az indokolás adós maradt. Vélhetően arra kívánt hivatkozni az előterjesztő, hogy a magasabb összegű követelések esetén már olyan magas az ellentmondások aránya, hogy felesleges kötelezővé tenni az FMH igénybevételét, mert ezek a jogviták végül úgyis perben dőlnek el. Bizonyára voltak erre vonatkozó elemzések, ${ }^{41}$ de nem ismerjük a jogalkotói döntést alátámasztó adatokat. A következő - az FMH elleni ellentmondás arányaival kapcsolatos - kérdés tehát az, hogy van-e, ha van, akkor milyen típusú és milyen erős összefüggés az érvényesített követelés értéke és az ellentmondás, azaz a perré alakulás valószínủsége között.

A végső kérdés pedig az, hogy a követelés értéke alapján lehet-e előre jelezni az ellentmondás valószínűségét? Másként megfogalmazva megfelelő klasszifikátor-e a FMH-k kimenetele szempontjából az érvényesített követelés összege? Továbbá hogyan lehet meghatározni az alsó korlát optimális értékét? Összegszerủen menynyi az, ehhez képest indokolt volt-e egyáltalán a módosítás, és helyesen határozta-e meg azt a jogalkotó 3 millió forintban az új Pp.-ben az általa végzett hatásvizsgálatok alapján? A kérdésekre a válaszokat statisztikai módszerekkel kerestem a következők szerint.

\section{ALKALMAZOTT MÓDSZER}

\section{1 ÜGYFORGALOM}

Az érkezett FMH-k és a perek száma között meglévő esetleges összefüggést és a perek számának csökkenésével kapcsolatos, az új Pp. indokolásában deklarált jogalkotói várakozást igazolandó elsőként áttanulmányoztam az érkezett FMH kibocsátása iránti kérelmek (a továbbiakban: érkezett FMH-k) és a perek számának alakulására vonatkozó ügyforgalmi adatokat a korábbi - jelentős alsó értékhatár módosulásokat eredményező - jogszabályváltozásokat megelőző és követő években. Azt vizsgáltam, hogyan változott az érkezett FMH-k és a perek száma és egymáshoz viszonyított aránya.

Abban az időszakban, amelyre vonatkozóan az ügyforgalmi adatok - legalább nagy vonalakban - hozzáférhetők, kétszer emelkedett jelentősebben az alsó korlát értéke. Az egyik ilyen alkalom a felülvizsgálati eljárásnak a Pp.-ben és az ehhez kapcsolódó jogszabályokban történő megteremtéséről szóló 1992. évi LXVIII. tör-

${ }^{41}$ Erre utal a szakértői javaslat érvrendszere: VARGA-ÉLESS (2. lj.) 802. 
vény (a továbbiakban: V. Ppn.) hatálybalépése volt 1993. január 1-jén. ${ }^{42}$ A törvény 16. §-ának (1) bekezdése a Pp. 313. §-ának (2) bekezdését módosítva a korábbi 5000 forintról ${ }^{43} 50000$ forintra, tehát egy lépésben tízszeresére emelte az alsó korlátot. A másik alkalom a X. Ppn. már említett hatálybalépése 2009. január 1-jén, amikor 200000 forintról ötszörösére, azaz 1 millió forintra emelkedett az alsó korlát ${ }^{44}$.

Az esetleges hatások detektálása érdekében áttekintettem az 1992-1993 és 20082009 közötti évek közzétett bírósági ügyforgalmi adatait. Az adott esetben ez elegendő volt, mivel az Fmhtv. hatálybalépését, 2010. július 1-jét megelőzően az FMH kibocsátása még a bíróságok hatáskörébe tartozott, ${ }^{45}$ tehát az FMH-kal kapcsolatos ügyforgalmi adatok a bírósági statisztikában jelentek meg. Az adatokat vizsgálva azonban megállapítható, hogy a fizetési meghagyásos eljárások száma nem szerepel külön a közzétett adatokban, csak a nemperes ügyek között. Azonban a helyi, a munkaügyi és a megyei bíróságok elsőfokú nemperes ügyeinek döntő többségét az FMH-k tették ki. Jól jelzi ezt, hogy az első olyan évben, amikor hatáskör hiányában már egyáltalán nem érkezett FMH kibocsátása iránti kérelem a bíróságokra, akkor a nemperes ügyek száma egy nagysárenddel csökkent. A 2009. évi 662 256-röl az összes polgári, gazdasági és munkaügyi (magánjogi) nemperes ügy száma 2011-re 75 631-re zuhant. ${ }^{46} \mathrm{~A}$ bírósági statisztikában megjelenő nemperes ügyeknek tehát majdnem 90\%-át (662 256-75631/662 256=0,8857) az FMH-k tették ki. Ezért, ha 1993-ban vagy 2009-ben változást tapasztalunk a magánjogi nemperes ügyek számában, akkor ezt döntően az FMH-k számváltozásának tudhatjuk be.

Sajnálatos módon 1992-1993-ból a megyei bíróságok ügyforgalmi adatai nem elérhetők, pedig a megyei bíróságok éppen 1993. január 1-jétől váltak jogosulttá FMH kibocsátására. ${ }^{47}$ De a későbbiekben látni fogjuk, hogy ez utóbbiak ügyforgalma egy nagyságrenddel alatta van a helyi bíróságokénak, tehát az adtok hiánya nem okoz számottevő eltérést. Nem láthatók továbbá a közzétett adatok között a munkaügyi bíróságok nemperes ügyforgalmára vonatkozó adatok sem. Ám ennek sincs jelentősége, mert a munkaügyi bíróságok ekkor még nem bocsáthattak ki FMH-t. ${ }^{48}$

${ }^{42}$ Az V. Ppn. 28. §-ának (1) bekezdése alapján lépett hatályba.

${ }^{43}$ A Pp. módositásáról szóló 1972. évi 26. törvényerejü rendelet 54. §-a állapitotta meg 1973. január 1-jétöl.

${ }^{44}$ Közben a Pp. módositásáról szóló 1995. évi LX. törvény (a továbbiakban: VI. Ppn.) 26. §-a 1995. augusztus 29-tỏl 100 000, a már említett VII. Ppn. 33. §-ának (2) bekezdése pedig 1998. január 1-jétől 200000 forintra emelte az alsó korlátot, de e két alkalommal az kevésbe jelentős mértékben, „csak” kétszeresére emelkedett.

${ }^{45}$ A részletes szabályokat a Pp. FMH-s eljárásról szóló korábban hatályos XIX. fejezete tartalmazta.

${ }^{46}$ Adatok forrása: www.birosag.hWugyforgalmi-adatok?title $=\&$ ev $=\&$ page $=2$.

${ }^{47}$ Az V. Ppn. 31. §-ának c) pontja ugyanis hatályon kívül helyezte a Pp. 313. §-ának a megyei bíróság hatáskörét az FMH kibocsátását illetően korábban kizáró (3) bekezdését.

${ }^{48}$ Erre csak a Pp.-ek - a VI. Ppn. 28. §-a által beiktatott - 350. §-a alapján váltak jogosulttá, a VI. Ppn. 30. §-ának (1) bekezdése értelmében 1995. augusztus 29-töl (a VI. Ppn. a Magyar Közlöny 1995. évi 56. számában jelent meg 1995. június 30-án). 


\subsection{AZ ELLENTMONDÁSOK ARÁNYA}

Az érvényesített követelés összege és az ellentmondás valószínűsége közötti - az indokolás szerint a jogalkotó által az alsó korlát emelése körében figyelembe vett kapcsolatot a 2012-ben érkezett FMH-k útján érvényesített követelések összegeinek elemzése alapján tekintettem át. ${ }^{49}$ Első lépésként meghatároztam az ellentmondások arányát összesen és az FMH-k egyes - az érvényesített követelés összege alapján kialakított - csoportjaiban külön-külön is. A kapott adatokat grafikonon ábrázoltam és elemeztem. Majd megfordítva, a másik oldalról is vizsgáltam az összefüggést: ezúttal az eljárás kimenetele, azaz aszerint bontottam két csoportra az FMHkat, hogy perré alakultak, vagy jogerőre emelkedtek-e. Az érvényesített követelések összegéről leíró statisztikákat készítettem, majd összehasonlítottam a két csoportot. A Mann-Whitney U-teszt segítségével elvégzett hipotézisvizsgálat előtt - a paraméteres tesztek alkalmazásának lehetőségében bízva - Kolmogorov-Smirnovteszttel vizsgáltam az eloszlások normalitását, és a Lilliefors-teszttel korrigált p értékeket vettem figyelembe.

A hipotézisvizsgálat eredményére figyelemmel khí négyzet próbával kapcsolatvizsgálatot végeztem az eljárás kimenetele és az érvényesített követelés összege mint az FMH-t jellemző két független változó között. Mivel előbbi nominális változó, utóbbi pedig kontinuus, ezért közöttük vegyes kapcsolat lehet. Ezért az érvényesített követelés összegéből, mint a kontinuus változóból ordinálisat képeztem, és az érvényesített követelés összege alapján hét csoportot alakítottam ki a 2012ben érkezett FMH-kon belül. ${ }^{50} \mathrm{~A}$ kapcsolat szorosságát pedig - a kontingenciatábla erős aszimmetriájára tekintettel - a Cramer-féle kontingencia együttható kiszámításával becsültem meg.

\subsection{ROC ANALÍZIS}

A jogalkotó alsó korlát összegszerűségére vonatkozó döntésének ellenőrzése és az optimális érték meghatározása érdekében ROC analízist végeztem. A ROC analízis az angol receiver operating characteristic („vevő müködési karakterisztika”) kifejezés rövidítése. ${ }^{51}$ Magyarul vágópont-analízisként szokták említeni. E statisztikai eljárás lényegében a kétosztályos klasszifikátorok minőségellenőrzésére szolgá-

\footnotetext{
${ }^{49}$ Adatok forrása: MOKK, egyedi adatkérés alapján.

${ }^{50}$ Amikor a csoporthatárokat megvontam, arra kellett figyelemmel lenni, hogy - a 3. számú diagram alapját képező 100000 forint szélességű sávokat alkalmazva - drasztikusan leesett a magasabb értéksávokba tartozó esetek száma. Márpedig a khí négyzet próba elvégzésének feltétele, hogy a tényleges adatok alapján számított várható gyakoriságokat tartalmazó táblázat rubrikáinak maximum 20\%-ában lehet a várt gyakoriság értéke kevesebb, mint 5 és egyben sem lehet 1 alatt. Ezt figyelembe véve alakítottam ki a csoportokat, és így a tapasztalt alapján számított várható gyakoriságok értéke a 14 cella közül csak egy esetben volt 5, és egy esetben sem volt 1 alatt. A khí négyzet próba elvégzésének valamennyi feltétele tejesült tehát.

51 FAZeKasné Kis Mária: „ROC analízis alkalmazása” Acta Agraria Debreceniensis 2002/1. 4-7., https://doi.org/10.34101/actaagrar/1/3511.
} 
ló módszer. ${ }^{52}$ A második világháborúban fejlesztették ki radarjelek elemzése érdekében (innen ered a különös név), és az 50-es években kezdték szélesebb körben, leginkább orvosi diagnosztikai eljárások hatékonyságának vizsgálatára és összehasonlítására alkalmazni.

Ez utóbbi területen a módszer segítségével azt elemzik, hogy egy adott változóra irányuló vizsgálat (pl. bizonyos enzim vérszintje) mennyire alkalmas egy bizonyos betegség (pl. bizonyos típusú daganat) diagnosztizálására. Hol érdemes megvonni a vizsgált paraméter mért értékének értékhatárát, azaz a vágópontot annak érdekében, hogy a lehető legbiztosabban elkülönítsük a betegeket (daganatos) az egészségesektől (nem daganatos). Az optimális természetesen az, ha a vizsgált paraméter alapján minden beteg azonosítható, de egyetlen egészségeset sem nyilvánítunk betegnek. Erre akkor van esély, ha az adott paraméter alapján a betegek és az egészségesek teljes biztonsággal elkülöníthetők, azaz a két csoport között nincs átfedés, hisztogramjuk nem takarja egymást. Ez persze nem túl gyakori, a két csoport vizsgált változójának eloszlása a legtöbb esetben fedi egymást (lásd 1. számú diagram). Ehhez képest, a vizsgált diagnosztikus módszer által adott eredmény és a betegség fennállása között négyféle logikai kapcsolat lehet, amelyet az egyes kategóriákba tartozó esetek számát tartalmazó kontingenciatáblában (lásd 1. számú táblázat) foglalhatunk össze, ami lényegében egy klasszifikációs mátrix. A lehetséges kategóriák betűjeleit az 1. számú diagramon is feltüntettem.

Tegyük fel, hogy az adott betegségben szenvedők (daganatosok) vizsgált paramétere (enzimszintje) általában magasabb értéket mutat, mint az egészségeseké. Ebben az esetben az első csoportba azok az esetek tartoznak, amelyeket a diagnosztikus módszer alapján betegnek tartanak, mert a mért paraméter értéke a vágópont felett van, és valóban betegek is (az angol true positive kifejezés rövidítése alapján a továbbiakban: TP). A másodikba azok, akiket a vizsgálat alapján egészségesek közé sorolnak, mert a mért paraméter értéke a vágópont alatt van, és tényleg egészségesek (az angol true negative kifejezés rövidítése alapján a továbbiakban: TN). A harmadik csoportot azok alkotják, akiket az alkalmazott módszer alapján betegnek minősítenek, mert magas az enzimszintjük, pedig valójában egészségesek (az angol false positive kifejezés rövidítése alapján a továbbiakban: FP, más megközelítésben elsőfajú hibának is tekintik). Az utolsó csoport pedig ennek ellentéte: azok, akiket a teszt alapján egészségesnek gondolnak az alacsony enzimszintjük miatt, de valójában betegek (az angol false negative kifejezés rövidítése alapján a továbbiakban: FN, másodfajú hibának is mondják).

${ }^{52}$ DudÁs László: Fontos jellemzők kiválasztása permutációk segítségével (Budapest 2011) 9-10., www.docplayer.hw/301917-Fontos-jellemz-k-kivalasztasa-permutaciok-segitsegevel.html. 


\section{1. számú diagram}

Két hipotetikus csoport hisztogramja egy meghatárotott hipotetikus változó értéke alapján és a két csoportot elhatároló vágópont

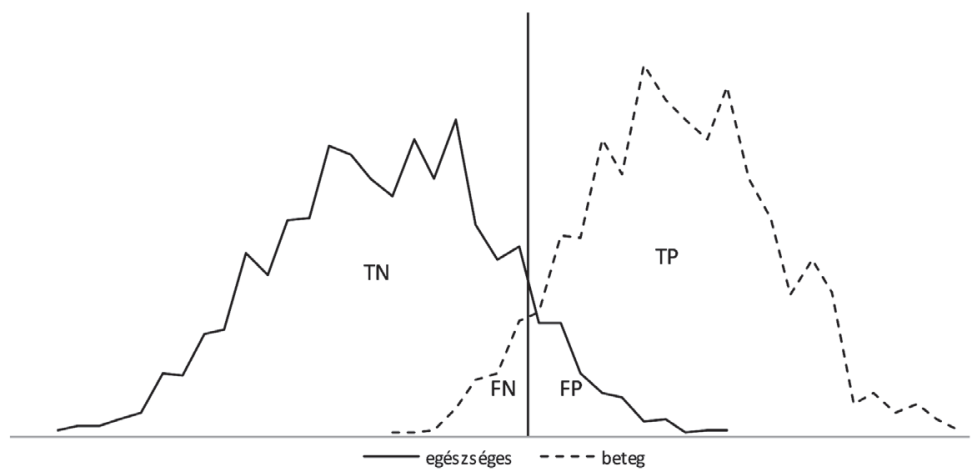

Az egyes csoportba tartozók száma alapján a következő mutatószámokat számolhatjuk ki. ${ }^{53}$ A módszer szenzitivitása (az angol sensitivity kifejezés rövidítése alapján a továbbiakban: SEN) azt mutatja meg, hogy a teszt segítségével a tényleg betegek mekkora hányadát sikerül diagnosztizálni ( $\mathrm{SEN}=\mathrm{TP} /(\mathrm{TP}+\mathrm{FN})$, értéke 0 és 1 között változik. A módszer specificitása (az angol specificity kifejezés rövidítése alapján a továbbiakban: SPEC) azt jelzi, hogy az egészségesek mekkora hányadát sikerült azonosítani (SPEC $=\mathrm{TN} /(\mathrm{TN}+\mathrm{FP})$, értéke szintén 0 és 1 között változik. Optimális, egymástól teljesen elkülönülő eloszlás esetén mindkettő értéke 1, azaz 100\%, mert a FP és a FN száma is 0 , és csak TP és TN esetek vannak. A módszer pozitív előrejelzési értéke, vagyis pontossága (az angol positive predictive value szó rövidítéseként a továbbiakban: PPV) azt jelenti, hogy a pozitív döntések mekkora hányada helyes (PPV=TP/(TP+FP)). Az eljárás negatív előrejelzési értéke (az angol negative predictive value szó rövidítéseként a továbbiakban: NPV) azt jelenti, hogy a nemleges döntések mekkora hányada helyes (NPV=TN/(TN+FN)).

A vágópont változtatásával természetesen a táblázat minden adata és a számított értékek is változnak. ${ }^{54} \mathrm{~A}$ vágópont adott esetben optimális értéke nem tisztán matematikai kérdés, mert azt befolyásolja a diagnosztizálni kívánt betegség súlyossága, a kezelés elmaradásának következményei, a pozitív diagnózis alapján alkalmazandó kezelés mellékhatásai stb. Ha például az ebolával fertőzöttek kiszűrése a cél, akkor nyilván olyan vágópontot érdemes választani, ahol - a FP esetek számá-

${ }^{53}$ Bodon Ferenc: Adatbányászati algoritmusok (Budapest 2010) 160-161., http://www.cs.bme.hw/ bodon/magyar/adatbanyaszat/tanulmany/adatbanyaszat.pdf.

${ }^{54}$ Alacsonyabb vágópont választása esetén az FP esetek száma nőni, a FN esetek száma csökkenni fog, tehát a vizsgálati módszer specificitása csökken (egyre több téves pozitív diagnózisunk lesz), szenzitivitása nő (egyre kevesebb beteg csúszik át a szürőn, és marad kezelés nélkül). A vágópont emelése esetén a FP esetek száma csökkenni, a FN esetek száma nőni fog, tehát a vizsgálati módszer specificitása nő (egyre inkább csak a valóban betegre mondjuk azt, hogy beteg), szenzitivitása csökken (egyre több beteg nem kap majd kezelést, mert azt gondoljuk a vizsgálat alapján, hogy egészséges, pedig valójában beteg). 
tól és a SPEC, valamint a SEN+SPEC értékétől függetlenül - kiemelkedően magas a SEN értéke és a FN esetek száma 0 vagy elhanyagolható...

A különböző vágópont értékekhez tartozó SEN és 1-SPEC értékek vizuális megjelenítésére szolgál a ROC görbe, amely egy olyan diagram, amelynek x-tengelyén az 1-SPEC, más szóval fals pozitív arány (FP/(TN+FP), az y-tengelyén pedig a SEN 0 és 1 között változó értékeit tüntetik fel. Ha a vizsgálati módszer nem alkalmas a betegek és az egészségesek elkülönítésére, akkor a ROC görbe valójában egy az origóból az egy egység oldalhosszúságú négyzet jobb felső sarkába tartó egyenes lesz. Ilyenkor a görbe alatti terület (az angol area under curve kifejezés rövidítéséből a továbbiakban: AUC) az egységnégyzet fele, azaz 0,5. Ha a másik szélsőséges eset valósul meg és betegek, valamint az egészségesek a mért paraméter alapján teljesen elkülönülnek, nincs átfedés a két halmaz között, akkor a ROC görbe - ez esetben valójában egy fordított L alak - az origóból indulva érinti az egységnégyzet bal felső sarkát, és egyenesen a jobb felső sarokba tart, az AUC=1. Minden más köztes esetben az ábrán egy szabálytalan karakterisztikájú görbe látszik. A vizsgált diagnosztikus módszer hatékonyságát az mutatja, hogy a görbe mennyire távolodik el az átlós egyenestől és mennyire közelíti meg a bal felső sarkot, azaz mennyire esik közel az AUC értéke az 1-hez. Vágópontként a vizsgált paraméter azon értékét érdemes választani, ahol az görbe adott pontjához tartozó SEN - SPEC értékpárok összege a maximális, de ezt befolyásolják egyéb szempontok is.

Vegyük észre, hogy a tanulmány által vizsgált probléma éppen ennek az egészséges-beteg dilemmának az analógiája a következők szerint: Mivel ez a kívánatos vagy optimális helyzet, tekintsük a követelések azon csoportját, ahol valójában nincs érdemi jogvita a felek között - azaz FMH útján való érvényesítésük esetén jogerőre emelkednének - az egészségesekkel, ahol tényleges jogvita van a felek között, és FMH-ból perré alakulnának - mivel ez a kedvezőtlen eset - a betegekkel analóg csoportnak. A vizsgált diagnosztikus paraméternek, a klasszifikátornak pedig esetünkben az érvényesített követelés összege felel meg. Az a várakozásunk, és úgy tűnik a jogalkotóé is az volt, hogy a magasabb összegű követelések érvényesítése érdekében kibocsátott FMH-k közül több alakul perré a kötelezett ellentmondása folytán, tehát ezeket érdemes eleve a peres útra irányítani. A vizsgált problémára adaptált klasszifikációs mátrixot az 1 . sz. táblázat tartalmazza.

\section{1. számú táblázat}

A ROC analízis alapját képező, a tanulmány tárgyára adaptált klasszifikácós mátrix

\begin{tabular}{lllll}
\hline & \multicolumn{5}{c}{ tényleges besorolás } & & számított mutatók \\
\cline { 3 - 5 } & & $\begin{array}{l}\text { van érdemi jogvita (FMH } \\
\text { esetén perré alakul) }\end{array}$ & $\begin{array}{l}\text { nincs érdemi j } \\
\text { ogvita (FMH esetén } \\
\text { jogeröre emelkedik) }\end{array}$ & PPV $=\mathrm{TP} /(\mathrm{TP}+\mathrm{FP})$ \\
\hline $\begin{array}{l}\text { klasszifiká- } \\
\text { tor szerinti } \\
\text { besorolás }\end{array}$ & $\begin{array}{l}\text { követelt összeg } \\
\text { alsó korlát felett }\end{array}$ & $\mathrm{TP}$ & $\mathrm{FP}$ & $\mathrm{NPV}=\mathrm{TN} /(\mathrm{TN}+\mathrm{FN})$ \\
\cline { 2 - 5 } & $\begin{array}{l}\text { követelt összeg } \\
\text { alsó korlát alatt }\end{array}$ & $\mathrm{FN}$ & $\mathrm{TN}$ & \\
\hline & $\begin{array}{l}\text { számított } \\
\text { mutatók }\end{array}$ & $\mathrm{SEN}=\mathrm{TP} /(\mathrm{TP}+\mathrm{FN})$ & $\mathrm{SPEC}=\mathrm{TN} /(\mathrm{TN}+\mathrm{FP})$ & \\
\hline
\end{tabular}


A TP esetek itt azok, amelyekről a követelés magasabb összege alapján azt gondoljuk, hogy van érdemi jogvita, ezért FMH-ból perré alakulnának, és így is történt, vagy így történne. A FN az az igény, amelyröl a követelés viszonylag alacsonyabb összege miatt azt gondoljuk, hogy nincs érdemi jogvita, és jogerőre emelkedik, pedig perré alakulna. A FP-k azok, amelyeknél a követelés összege magas, még sincs valódi jogvita, FMH esetén nem mondott vagy mondott volna ellent a kötelezett. A TN ügyek pedig azok, amelyekről a követelés alacsony összege miatt helyesen azt gondoljuk, hogy nincs érdemi jogvita, és FMH kibocsátása esetén jogerőre emelkednek vagy emelkednének.

A kérdés pedig az, hogy az érvényesített követelés összege alapján elkülöníthető-e egymástól az igények két csoportja: az, ahol van érdemi jogvita, ezért felesleges FMH-s útra terelni, és az, ahol nincs, ezért felesleges perindításra kényszeríteni a jogosultat. Ha a két csoport elkülöníthető, akkor milyen hatékonysággal, milyen „diagnosztikus” értéknél érdemes meghúzni a határvonalat. Milyen követelés összegtől tekintsünk „betegnek” egy ügyet, azaz irányítsuk peres útra azon az alapon, hogy úgy gondoljuk FMH útján való érvényesítés esetén úgyis ellentmondással élne a kötelezett. A cél, hogy minél kevesebb olyan ügy esetében tegyük kötelezővé az FMH benyújtását, amiben úgyis ellentmondással élnek, és perré alakul, ugyanakkor minél kevesebb olyan igényt engedjünk közvetlenül perben érvényesíteni a bíróság előtt, amely FMH esetén jogerőre emelkedhetett volna.

A kérdés eldöntése érdekében azokat az állami úton történt igényérvényesítéseket kellett vizsgálnom, amelyekben az érvényesített követelés összege az alsó korlát új Pp. hatálybalépése előtti értéke, azaz 1 millió forint felett volt, nem haladta meg ugyanakkor a felső korlát Fmhtv. 3. §-ának új (3) bekezdése által ezzel egyidőben megállapított ${ }^{55} 30$ millió forintos értékét. ${ }^{56} \mathrm{E}$ követelések egy részét a jogosultak - választásuktól függően - FMH útján érvényesítették, más részük iránt közvetlenül bíróság előtt indítottak pert. Ezért mindkét igényérvényesítési úton indult ügyek adataira szükségem volt. A vizsgálat elvégzésére a 2012-ben indult FMH-k és bírósági perek adatait használtam fel. Egyrészt erre az időszakra állt rendelkezésemre mind az FMH-k, mind a perek tekintetében is a teljes adatbázis, másrészt alappal feltételezhetjük, hogy a jogalkotó is ezekből indult ki. ${ }^{57}$

Kigyűjtöttem tehát az FMH-k közül azokat, ahol az érvényesített követelés összege az alsó és felső korlát közé esett: 28422 ilyet találtam. Ezeket csoportosítottam

${ }^{55}$ Az új Ppé. 74. §-ának (2) bekezdése az új Pp. hatálybalépésével egyidejűleg új rendelkezést léptetett az Fmhtv. 3. §-ának (3) bekezdése helyébe. Az új (3) bekezdés - a megelőzően hatályos 4(a) bekezdésben írt 400 millió forint helyett - azt mondja ki, hogy az a pénzkövetelés nem érvényesíthető FMH-s eljárás útján, amelynek az új Pp. 21. és 22. §-a szerint számított összege a 30 millió forintot meghaladja.

${ }^{56}$ Abból a szempontból ugyanis, hogy 2018-ben hol kellett volna meghúzni az alsó korlát értékét figyelmen kívül hagyhatók voltak azok az 1 millió forint alatti követelések iránti ügyek, amelyek már addig is csak FMH útján voltak érvényesíthetők. Továbbá azok az új felső korlát feletti követelések iránt indult ügyek is, amelyeket éppen ekkor zárt ki a jogalkotó az FMH hatálya alól.

57 Erre utalnak az új Pp. koncepcióját megalapozó tanulmányban - REviczKY-SzÉcsÉNYI-NAGY (2. lj.) 621.) és a szakértői javaslatban (VARGA - ÉLESS (2. lj.) 802. - közölt adatok; minden bizonnyal ezeket vette a jogalkotó is alapul a Pp. 254. §-ához füzött indokolásban írtakhoz. 
aszerint, hogy jogerőre emelkedtek (22 901 eset), vagy perré alakultak (5521 eset).

Nem volt ilyen egyszerű a helyzet a 2012-be indult peres ügyek esetében. Ez egyrészt arra vezethető vissza, hogy nem tudjuk, hogy az alsó korlát emelése hány, abban az évben közvetlenül a bíróság előtt érvényesített magánjogi igényt érintene, azaz az alsó korlát emelésével elvileg hány ügyet terelhetnénk FMH-s útra.

Ennek egyik oka az, hogy a keresetlevéllel érvényesített igényeknek két csoportjuk van. Az első csoport az egyébként is kizárólag bírósági útra tartozó követelések csoportja, ahol a per tárgya (nem pénz fizetésére kötelezésre irányuló igények) miatt eleve kizárt az FMH útján való érvényesítés lehetősége (házassági perek, gondnokság alá helyezési perek, tulajdonjog megállapítása iránti perek stb.). A másik csoport pedig, az FMH-s eljárásban is érvényesíthető követelések (tisztán pénzkövetelések) csoportja, ahol elvileg módja lett volna rá, de a felperes mégsem kívánt élni az FMH lehetőségével. A bírósági lajstromrendszerben sajnos nem rögzítik a vizsgálathoz szükséges pontossággal a perek tárgyát, azaz az ügyek jelentős hányadában nem töltik ki az ennek rögzítésére szolgáló mezőt. Ennek következtében nem lehetett megállapítani, hogy a 2012-ben közvetlenül bíróság előtt indult perek közül hány irányult kizárólag pénzfizetésre kötelezésre, azaz - tárgyánál fogva - mennyi terelhető egyáltalán FMH-s útra.

A másik ok, hogy sok esetben a pertárgy értékét, azaz az érvényesített követelés összegét sem rögzítették a lajstromban, tehát a pertárgy alapján ugyan bizonyosan FMH útján is érvényesíthető pereknél sem lehetett pontosan megmondani, hány esetben volt a követelés összege az új felső korlát alatt.

E szempontokat szem előtt tartva kigyűjtöttem a bírósági adatbázisból a 2012-ben indult, az FMH útján való érvényesítés - összegszerủ és az ügy tárgya szerinti - feltételeinek megfelelő ügyeket (a továbbiakban: potenciális FMH-k). A 159454 keresetlevéllel (tehát nem FMH elleni ellentmondás folytán) indult per közül csak 63733 olyan per volt, amely a tárgya alapján elvileg egyáltalán érvényesíthető lett volna FMH útján is. Ezek közül azonban 23112 esetben a lajstromozáskor nem rögzítették a pertárgy értékét, és csak 15762 ügy esetében volt megállapítható, hogy a pertárgy érték több volt, mint 1 millió forint és kevesebb volt, mint 30 millió forint, tehát bizonyosan akár FMH útján is érvényesíthető lett volna, azaz potenciális FMH-nak tekinthető.

A peres ügyekkel kapcsolatos bizonytalanság másik forrása az volt, hogy nem tudhatjuk, hogy a potenciális FMH-k közül hány ügyben volt érdemi jogvita. Milyen lett volna az ellentmondási arány, ha ezek az ügyek nem perként, hanem FMHként indulnak. Azaz hogyan csoportosítsuk őket abból a szempontból, hogy FMHként indulva jogerőre emelkednének, vagy perré alakulnának: a klasszifikációs mátrix melyik oszlopában kell feltüntetnünk őket. A bizonytalanságot az okozza, hogy a jelenleg FMH útján érvényesített követelések esetében ugyan ismerjük az ellenmondási arányt, de felmerül a kérdés, hogy a potenciális FMH-k esetén is ugyanezzel az ellentmondási aránnyal számolhatunk-e.

Véleményem szerint a válasz egyértelműen nem. Abból indultam ki, hogy jelenleg minden bizonnyal azokat az igényeket viszik a jogosultak önként FMH-s útra, ahol a saját értékelésük szerint is alappal bízhatnak abban, hogy a kötelezett nem mond ellent, mert biztos jogi alapokon nyugszik követelésük, nem számítanak valódi jogvitára. A bíróság előtt érvényesített igények esetében tehát maguk a jogosul- 
tak is magasabb ellenmondási valószínűséggel számolnak, ezért nem kísérlik meg az FMH-s eljárást. Erre tekintettel helyesen tesszük, ha úgy kalkulálunk, hogy a potenciális FMH-k esetében az ellentmondási arány minden pertárgy érték kategóriában - és a magasabbak esetén egyre inkább - nagyobb lesz, mint a most FMH útján érvényesített igények azonos pertárgy érték sávjában. Másrészt azonban az is biztos, hogy még így sem nyújtanának be minden potenciális FMH-s ügyben ellenmondást, tehát az ellenmondási ráta még a legmagasabb pertárgyértékủ potenciális FMH-k esetén sem fogja elérni a 100\%-ot.

Azt vettem ezért alapul, hogy az 1 millió forintos követelések esetén az ellentmondási arány azonos lesz az 1 millió forint iránti FMH-k esetében mért ellenmondási aránnyal, ezért azt 12\%-nak vettem (lásd a 3. számú diagram). Ezt az arányt - a pesszimista forgatókönyvet alapul véve - a legmagasabb követeléskategóriáig lineárisan 90\%-ra emeltem. A potenciális FMH-k minden értéksávba eső csoportjából véletlenszerủen kiválasztottam az ügyek adott sávra jellemző ellentmondási aránynak megfelelő hányadát. Ezt az összesen 7649 pert az FMH adatbázis szerint ténylegesen perré alakult FMH-k halmazához csoportosítottam. A maradék 8113 potenciális FMH-t úgy tekintettem, amely FMH útján való érvényesítés esetén jogerőre emelkedne, és a ténylegesen jogerőre emelkedett FMH-k csoportjához soroltam. Így két halmazt kaptam (lásd 2. számú diagram). Az egyiket (22 901 FMH plusz 8113 potenciális FMH, összesen 31014 ügy) a továbbiakban nevezzük az érdemi jogvita nélküli, FMH kibocsátása esetén jogerőre emelkedő ügyeknek. A másikat (5521 FMH plusz 7649 potenciális FMH, összesen 13170 ügy) pedig az érdemi jogvita miatt FMH-ból perré alakuló ügyeknek. Mindkét halmaz minden eleme esetében ismertem az érvényesített követelés összegét, tehát nem volt akadálya a ROC analízis lefuttatásának.

\section{2. számú diagram}

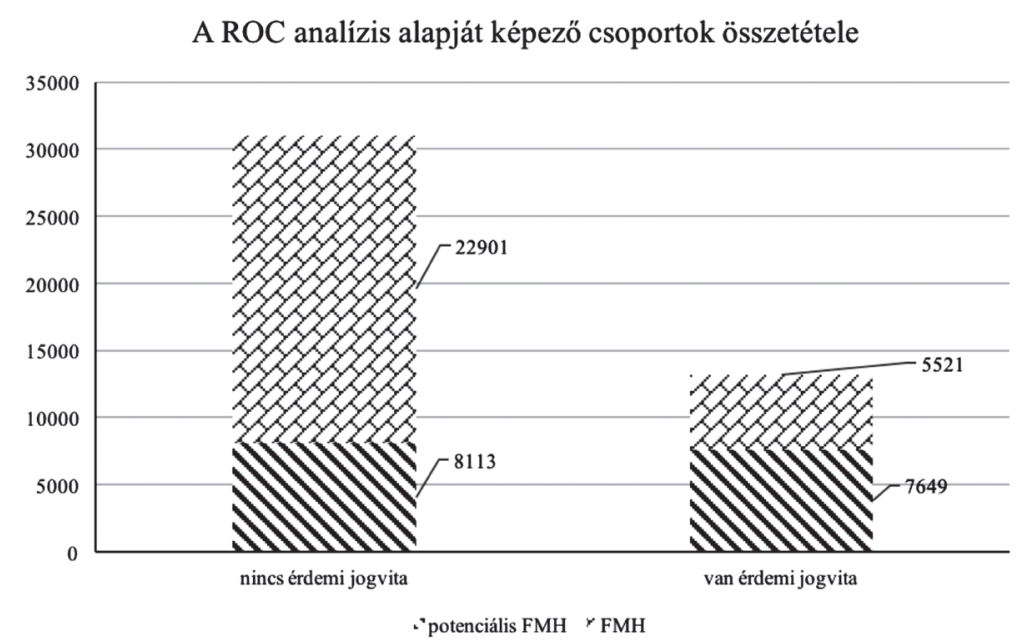


A szignifikancia szintet minden vizsgálat során 0,05-nek vettem. A statisztikai elemzéshez és az ábrák elkészítéséhez a MS Excel és az IBM SPSS programokat használtam.

\section{EREDMÉNYEK}

\section{1 ÜGYFORGALOM}

Az alsó korlát az első vizsgált alkalommal, 1993-ban tízszeresére emelkedett. Az ügyforgalmi adatokból azt látjuk, hogy a helyi bírósági polgári és gazdasági nemperes ügyek száma 352 760-ról 462 891-re nőtt. Emelkedett ugyanakkor a helyi bírósági polgári és gazdasági perek száma is 165 716-ról 199 930-ra.

A második vizsgált módosítás alkalmával a fentiek szerint az alsó korlát a X. Ppn. alapján ötszörösére emelkedett 2009. január 1-jén. Ez szintén igen jelentős emelkedés, és a 2008. évi és a 2009. évi adatokat összevetve látható is, hogy a várakozásoknak megfelelően a helyi és a munkaügyi, valamint a megyei bírósági nemperes ügyek száma is emelkedett. A helyi polgári és gazdasági nemperes ügyek száma 538 364-ről 620 597-re, a munkaügyi nemperes ügyeké 5938-ról 7129-re, a megyei bírósági polgári, gazdasági, közigazgatási nemperes ügyek száma pedig 29702 ről 34 530-ra. Ugyanakkor a helyi bírósági polgári peres ügyek száma 158558 ról 161 082-re, a helyi bírósági gazdasági peres ügyek száma 16 764-ről 17 329-re, a munkaügyi peres ügyek száma 24 086-ról 25 075-re, a megyei bírósági polgári, gazdasági peres ügyek száma pedig 17 499-ről 19 255-re, a magánjogi perek száma összesen 216 907-ről 222 741-re emelkedett.

\subsection{AZ ELLENTMONDÁSOK ARÁNYA}

Megállapítottam, hogy a 2012-ben érkezett 560043 FMH közül 526548 jogerőre emelkedett (94,02\%), és csak 33495 esetben (5,98\%) nyújtottak be ellentmondást, azaz alakult perré az eljárás. Az ellentmondás valószínűségét a pertárgy értéke alapján kialakított egyes kategóriákban külön-külön is vizsgáltam. A 2. számú táblázat utolsó sorának adatai alapján megállapítható, hogy bár az FMH-k útján érvényesített követelések összegének terjedelme - a legnagyobb FMH útján érvényesített követelés összege 1901367000 forint (!) volt - és szórása is óriási. 


\section{2. számú táblázat}

A 2012-ben érkezett FMH-k útján érvényesített követelések összegeinek leíró statisztikai adatai

\begin{tabular}{|c|c|c|c|c|c|c|c|c|c|c|c|c|}
\hline & Átlag & $\begin{array}{r}\text { Stan- } \\
\text { dard } \\
\text { hiba }\end{array}$ & $\begin{array}{r}\text { Medi- } \\
\text { án }\end{array}$ & $\begin{array}{l}\text { Mó- } \\
\text { dusz }\end{array}$ & Szórás & Variancia & $\begin{array}{r}\text { Csú- } \\
\text { csos- } \\
\text { ság }\end{array}$ & $\begin{array}{r}\text { Ferde- } \\
\text { ség }\end{array}$ & Tartomány & $\begin{array}{l}\text { Mini- } \\
\text { mum }^{58}\end{array}$ & Maximum $^{59}$ & $\begin{array}{r}\text { Darab- } \\
\text { szám }\end{array}$ \\
\hline perré alakult & 1307359 & 73826 & 215000 & 16400 & 13511452 & $1,826 * 10^{14}$ & 11860 & 90,633 & $1,901 * 10^{9}$ & 0 & $1,901^{*} 10^{9}$ & 33495 \\
\hline $\begin{array}{l}\text { jogeröre } \\
\text { emelkedett }\end{array}$ & 317812 & 3603 & 118567 & 16400 & 2614431 & $6,835 * 10^{12}$ & 13311,9 & 99,481 & 550000000 & 0 & 550000000 & 526548 \\
\hline összes FMH & 376995 & 5574 & 121481 & 16400 & 4171294 & $1,74 * 10^{13}$ & 80182 & 207,638 & $1,901^{*} 10^{9}$ & 0 & $1,901^{*} 10^{9}$ & 560043 \\
\hline
\end{tabular}

De az FMH-k 99,77\%-a esetében a követelés összege nem haladta meg a 10 millió forintot, 94,78\%-ánál az 1 millió forintot, és 43,76\%-a esetében még a 100000 forintot sem (lásd 3. számú táblázat). A követelések értékeinek ilyen megoszlására tekintettel a 10 millióforintig 100000 forint szélességű sávokat alakítottam ki, a 10 millió forint feletti összegre indított mindössze 1240 FMH-t pedig egy kategóriának tekintettem. Ezt követően minden egyes sávra nézve kiszámítottam az abba a sávba eső ellentmondással megtámadott FMH-k arányát. Az adatokat a 3. számú diagramon ábrázoltam.

A másik oldalról megközelítendő kérdést a 2012-ben érkezett FMH-kat az eljárás kimenetele szerint is két csoportra, a jogerőre emelkedett, valamint a perré alakult FMH-k csoportjára osztottam, és az érvényesített követelés összege szempontjából külön-külön is vizsgáltam. A két csoport leíró statisztikai adatait is a már hivatkozott 2. számú táblázat (első két sora) tartalmazza.

Az eloszlás sem az összes FMH, sem a két részsokaság esetén nem volt normális, az adatok logaritmikus transzformálását követően sem. Erre tekintettel a jogerőre emelkedett és perré alakult FMH-ban érvényesített követelések - a 2. számú táblázat alapján eltérőnek látszó - átlagára vonatkozó hipotézisvizsgálatot MannWhitney U-teszttel végeztem, melynek eredménye $\left(\mathrm{U}=1,82^{*} 10^{10}, \mathrm{Z}=51105,57\right.$, p=0,000) szerint a különbség szignifikáns.

${ }^{58}$ A 0 forintos összegre vonatkozó FMH minden bizonnyal téves adatrögzítés eredménye, de ilyen ügy mindössze háromszor fordult elő. Ezeket leszámítva a legkisebb érvényesített igény 1345 forint volt. Az adatbázis rendkívüli méretére és a bizonyosan valósnak tekinthető minimális igény összegére tekintettel tehát a fenti adatrögzítési hiba nem befolyásolja számottevően a kapott eredményeket.

${ }^{59} \mathrm{Ez}$ akként lehetséges, hogy 2012. március 15. előtt még nem volt felső korlát, azt - 400000 forintos összeggel - a bírósági végrehajtással kapcsolatos és egyéb igazságügyi tárgyú törvények módositásáról szóló 2011. évi CLXXX. törvény 108. §-ának (2) bekezdése vezette be 2012. március 15-től. A maximális értékű követelés iránti FMH tehát minden bizonnyal 2012. január 1. és március 14 . között érkezett. 


\section{3. számú diagram}

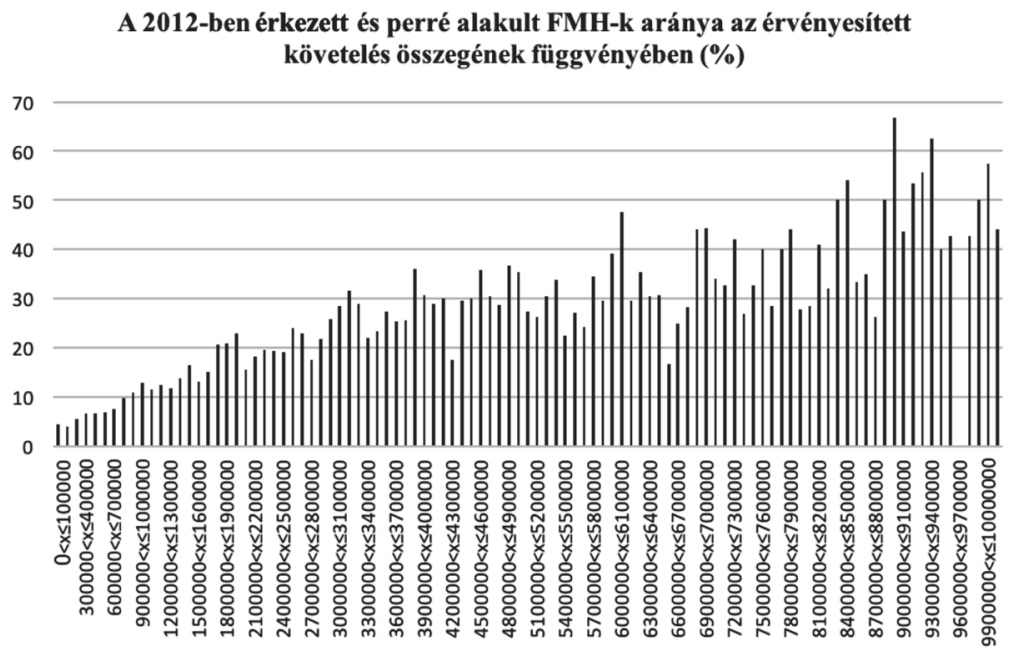

Az FMH-s eljárások kimenetele (ellentmondás és perré alakulás vagy jogerőre emelkedés, azaz a tényleges jogvita léte vagy hiánya), és az érvényesített követelés összege, mint az FMH-t jellemző két változó közötti kapcsolat feltárása érdekében elvégzett khí négyzet próba eredménye szerint df=6, khí négyzet=12 208,124, khí négyzet kritikus $=12,592, p=0,000$. A közöttük lévő kapcsolat szorosságát a Cramer-féle kontingencia együttható kiszámításával vizsgáltam: V=0,147, azaz a két változó közötti kapcsolat igen gyenge. Erre tekintettel erős kétségek merültek fel arra nézve, hogy egyáltalán lehet-e követelés összege alapján különbséget tenni az FMH-k között az érdemi jogvita léte vagy hiánya, az eljárások várható kimenetele szerint.

\section{3. számú táblázat}

A 2012-ben kibocsátott FMH-k tapasztalt gyakorisága az eljárás kimenetele, illetve a követelt összeg függvényében

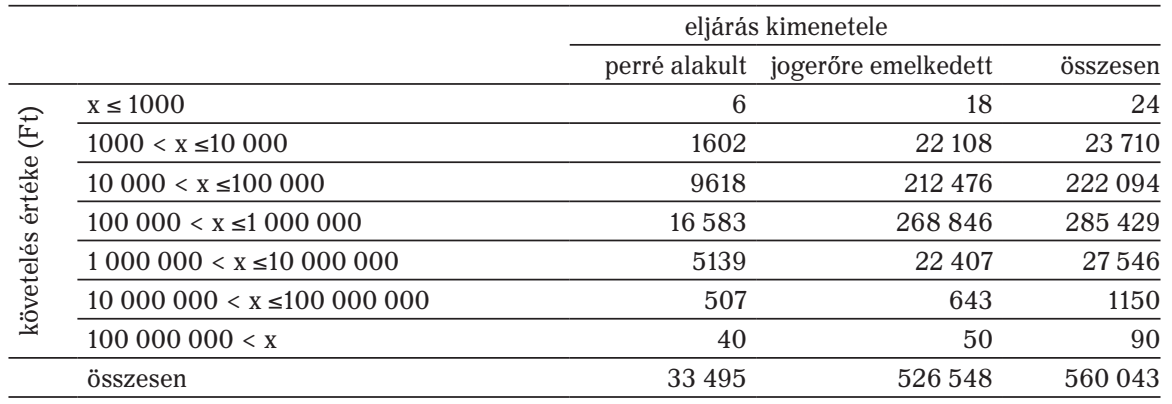




\subsection{ROC ANALÍZIS}

Az 1 millió és 30 millió forint közötti követelések iránti tényleges FMH-k és a fentiek szerint kiválogatott hipotetikus FMH-k 44184 elemű egyesített halmazára futtattam le a ROC elemzést, melynek végeredményét a 4 . számú diagram mutatja. Az AUC értéke 0,739 (standard hiba=0,003, p=0,000, 95\%-os konfidencia intervallum=0,734-0,744). A SEN+SPEC maximális értéke 1,37, 2980223 forint összegű vágópont esetén. A görbe valamennyi pontjának koordináta (SEN és 1-SPEC) értékeinek közlésétől a nagy elemszám következtében sok féle különböző összegű követelés, és emiatt kiemelkedően sok (32 488!!!) lehetséges vágópont miatt eltekintek.

\section{4. számú diagram}

A várhatóan perré alakuló és a jogerőre emelkedő FMH-k követelés értéke szerinti ROC görbéje

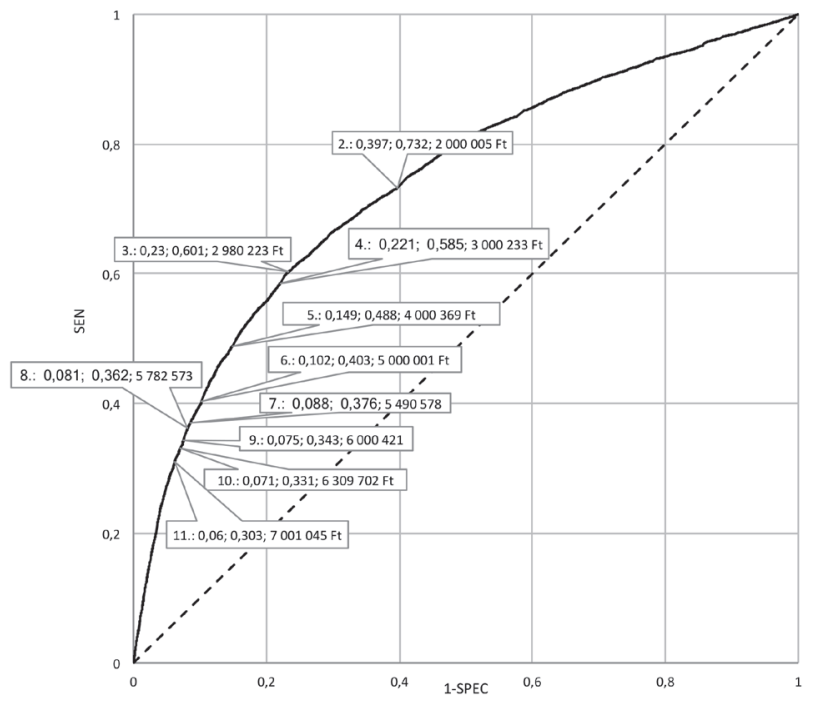

6. KÖVETKEZTETÉSEK

\section{1 ÜGYFORGALOM}

Az alsó korlát értéke és a perek száma közötti kapcsolat tekintetében a történeti adatok alapján megállapíthatjuk, hogy az 1993. évi tízszeres alsó korlát emelésének a jogérvényesítést az FMH-k irányába terelő hatása a nemperes ügyek számának jelentős, 31\%-os (462 891/352 760=1,3121) emelkedése (+110 131 nemperes ügy) alapján úgy tűnik megállapítható lenne. Kétségessé teszi ugyanakkor ezt a peres ügyek számának egyidejű majdnem 21\%-os (199 930/165 716=1,2064) emelkedése. Észre kell venni, hogy 1992-ben a jogvitás magánjogi ügyek legfeljebb 68\%-át (352 760/(352 760+165 716)=0,6803) kísérelték meg FMH útján érvényesíteni, addig 1993-ban 70\%-át (462 891/(462 891+199 930)=0,6983), ami - az FMH-s 
ügyek számának bizonytalanságára tekintettel - a tízszeres értékhatár emelkedéshez képest nem tűnik igazán jelentős különbségnek. A jogviták rendszerváltást követő robbanásszerủ megszaporodása miatt tehát nem észlelhető az alsó korlát emelésének a peres eljárások számának csökkenésében is megmutatkozó ügyforgalom módosító hatása.

A második jelentős emelés alkalmával, 2009-ben összesen 88 252-vel (662 256574 004), azaz 15\%-kal (662 256/574 004=1,1537) nőtt a nemperes ügyek száma, ami - egyéb jelentős ügyforgalmi változás hiányában - minden bizonnyal az FMH-k számának emelkedésére vezethető vissza. Ugyanakkor - a logikusan várható csökkenés helyett - ezúttal is emelkedett a peres ügyek száma, most összesen majdnem 3\%-kal ((161 082+17 329+25 075+19 255)/(158 558+16 764+24 086+ 17 499)=1,0268). Tehát 2009-ben ismét a peres ügyek egyéb tényezők - ez alkalommal minden bizonnyal a jogviták gazdasági válság okozta megszaporodása miatt emelkedő száma kissé megint elfedte az FMH alsó korlát emelésének hatását. A nemperes-peres ügyek egymáshoz viszonyított arányát illetően azonban megállapítható, hogy 2008-ban a jogvitás magánjogi ügyek maximum 73\%-a (574 004/ $(158558+16764+24086+17499+574004)=0,7257), 2009$-ben pedig már 77\%-a (662 256/(161 082+17 329+25 075+19 255+662 256)=0,7682) volt FMH. Egyéb - a nemperes ügyek számát számottevően - módosító hatás hiányában ez nyilván zömmel a szaporodó FMH-nak köszönhető, ami az ötszörös értékhatáremeléshez képest már jelentősebb növekedés.

Az értékhatár emelésekor tehát mindkét esetben kétségtelenül és jelentősen nőtt a nemperes ügyek, azaz döntően az FMH kibocsátása iránti kérelmek száma. De az FMH-s útra kényszerülő igényérvényesítések számának egyértelmű emelkedése ellenére egyik esetben sem lehet kimutatni a peres ügyek számának csökkenése formájában jelentkező egyidejủ változást, azaz a kettő közötti függvényszerủ kapcsolatot. Az ügyforgalomra ható számos egyéb tényező miatt nem tudunk egyértelmủ következtetést levonni arra nézve, hogy az alsó korlát korábbi jelentős emeléseinek pontosan milyen hatása volt a perek számára nézve. Egyértelmű történeti számadatokkal nem volt tehát alátámasztható az az alsó korlát 2018. évi emeléséhez kapcsolódó jogalkotói várakozás, hogy annak hatására jelentősen csökkenni fog a peres ügyek száma a bíróságokon. ${ }^{60}$ Pusztán azok alapján valójában a jogalkotó sem láthatta előre, hogy milyen következményekre számíthat. Nem tudjuk tehát, hogy ténylegesen milyen összefüggés van az alsó korlát összegszerűsége, valamint a peres és az FMH-s ügyek száma között.

$\mathrm{Az}$ új Pp. hatályba lépése után egyébként azt tapasztalhattuk, hogy jelentősen, 149 893+8432=158 325-ről 114 669+6474=121 143-ra csökkent a járásbíróságokon indult polgári és gazdasági perek száma és még radikálisabban a munkaügyi (12 667-ről 6170-re), valamint a törvényszéki polgári (13 225-ről 7316-ra) és gazdasági (6780-ról 4098-ra) pereké. Első látásra tehát úgy tűnhet, hogy most először még-

${ }^{60}$ Így különösen optimistának tűnik az új Pp. koncepciójának készítésekor megfogalmazott azon várakozás, hogy az alsó korlát - megvalósultnál jelentősebb - emelése esetén akár ötödére eshet a járásbíróságok 1 millió és 10 millió forint közötti tartományba eső vagyonjogi ügyérkezése - lásd: REVICZKY-SzÉCSÉNYI-NAGY (2. lj.) 622. 
is egyértelműen igazolódtak a jogalkotói várakozások az alsó korlát emelésének az igényérvényesítést a FMH irányába terelő hatását illetően. De a gyakorlati tapasztalatok alapján tudjuk, hogy ennek elsődleges oka sokkal inkább az alsó korlát emelésével egyidejüleg a keresetlevél tartalmi és formai követelményeire vonatkozó szabályok jelentős szigorítása volt. Hatására ugyanis általános jelleggel és érezhetően csökkent az állami úton való igényérvényesítési kedv. Ezt igazolja áttételesen, hogy az FMH-k száma is csökkent: a 2017-ben érkezett 559 408-cal ${ }^{61}$ szemben, 2018-ban már csak 491434 FMH-t bocsátottak ki a közjegyzők. ${ }^{62}$ A várt növekedéssel szemben tehát - a perek számával párhuzamosan - jelentősen csökkent az FMH-k száma is. A perek száma tehát nemcsak az FMH igénybevételének erősödő kényszere, és a jogviták FMH irányába terelődése, hanem a jogviták állami eszközökkel való érvényesítésének általában is csökkenő népszerűsége miatt is esett. Ezzel együtt azonban kétségtelen, hogy az igényérvényesítés súlypontja ezúttal is kis mértékben eltolódott FMH irányába: 2017-ben a magánjogi igények 74,54\%át (559 408/(158 3 25+12 667+13 225+6 780+559 408)=0,7454), míg 2018-ban 77,98\%-át (491 434/ $(121143+6170+7316+4098+491434)=0,7798)$ érvényesítették a jogosultak FMH útján. Ez említést érdemlő változás.

A perszám csökkenésének az FMH-szám emelkedésétől a korábbiakban rendre elmaradó mértékét magyarázhatja esetleg az, hogy a korábbi és az új alsó korlát közötti összegű követelések iránti, az új szabály alapján immár kényszerűen FMH útján érvényesített követelések esetén magasabb az ellentmondási arány. Azaz a jogosult a korábbi alsó korlát összegét meghaladó követelése érvényesítése érdekében már FMH kibocsátását kénytelen kérni, de e nagyobb összegű követelések esetén a kötelezettek már sokkal inkább élnek az ellentmondás lehetőségével.

\subsection{ELLENTMONDÁSOK ARÁNYA}

A rendelkezésemre álló 2012. évi adatok (lásd 2. számú táblázat) alapján az látható, hogy az FMH-k túlnyomó többsége (94,02\%-a) jogerőre emelkedett. Az 3. számú diagramból azonban az is megállapítható, hogy a jogerőre emelkedés valószínűsége nem egyformán jellemzi az ügyeket. A kis összegű (néhány tízezer forintos) követelések esetén a perré alakulási arány csak néhány (4-6)\%, és még az 1 millió forinthoz közeli összegek esetén is csak 10-12\%, ami azután 2 millió forint körül 15-20\%-ra emelkedik, 10 millió forintnál pedig - nagy szórás mellett - 40-50\% között mozog. A grafikon tehát ránézésre igazolja a jogalkotó vélekedését azzal kapcsolatban, hogy az ellentmondás előterjesztésének valószínűsége valamilyen pozitív korrelációban van az érvényesített követelés összegével.

A grafikon alapján ugyanakkor szemre úgy tűnik, hogy kb. 3 millió forintig kétségtelenül dinamikusan és egyenletesen emelkedik a perré alakuló eljárások ará-

${ }^{61}$ Adatok forrása: www.origo.hw/jog/20180227-magyar-orszagos-kozjegyzoi-kamara-fizetesi-meghagyas.html.

${ }^{62}$ Adatok forrása: www.origo.hW/jog/20190130-magyar-orszagos-kozjegyzoi-kamara-fizetesi-meghagyas.html. 
nya. Ám ezt követően az emelkedés dinamikája csökkenni látszik. Pusztán a látottak alapján is felvetődik tehát a kérdés, hogy 2018-ban az új alsó korlát miért pont 3 millió forint lett. Ha ezen összeg felett nem olyan meredek az ellentmondások arányának növekedése, akkor miért nem 5 millió, 8 millió vagy éppen 10 millió. ${ }^{63}$ Annyi mindenesetre bizonyos, hogy a kérdés pusztán vizuális alapon nem dönthető el.

A jogerőre emelkedett és perré alakult FMH-kat összehasonlítva - az új Pp. illetékes munkabizottságával egyezően ${ }^{64}$ - azt tapasztaltam, hogy a két csoportban jelentősen eltér az érvényesített követelések összegének átlaga. A jogerőre emelkedett FMH-k esetében a követelés átlagos értéke 317812 forint volt, míg a perré alakult FMH-k esetében 1307359 forint. De a nagy terjedelem és szórás, a rendkívül erősen ferdült és csúcsos (lásd 2. számú táblázat), továbbá a teszt statisztikával igazolt nem normális eloszlások miatt ránézésre nehezen volt megítélhető, hogy a különbség szignifikáns-e. Az elvégzett nemparaméteres próba alapján azonban a látott különbség erősen szignifikánsnak bizonyult. A nullhipotézist elvetve ezért levonhatjuk a következtetést: az érvényesített követelés összege szempontjából kétségtelenül különböznek egymástól a jogerőre emelkedett és a perré alakult FMH-k. Nagyobb értékủ követelés esetén nagyobb valószínűséggel mond ellent a kötelezett. És fordítva: a kisebb összegre kibocsátott FMH-kat nagyobb valószínűséggel hagyják jogerőre emelkedni a kötelezettek nyilván azon észszerű okból, hogy kis összegekért nem érdemes pereskedni az esetleges pervesztés kockázata miatt. Első látásra tehát erről az oldalról nézve is úgy látszik, hogy az eljárás kimenetele valamilyen módon összefüggésben van az érvényesített követelés összegével.

Ennek igazolása érdekében kapcsolatvizsgálatot is végeztem a két változó között. A khí négyzet próba szignifikáns különbséget mutatott ki tényleges és a várt gyakoriságok között. A változók függetlenségére vonatkozó nullhipotézist ezért elvetettem. A követelés összege tehát kétségtelenül kapcsolatban - az időbeli sorrendre tekintettel minden bizonnyal ok-okozati összefüggésben - van az ellentmondás valószínűségével: minél nagyobb a követelés, annál gyakoribb az ellentmondás. A Cramerféle kontingencia együttható meglehetősen alacsony értékéből $(V=0,147)$ azonban az is látható, hogy a két változó közötti kétségtelenül szignifikáns kapcsolat a látszat ellenére nagyon gyenge. Önmagában a követelés értéke alapján tehát nem vagy alig lehet következtetni a tényleges jogvita létére, azaz az eljárás kimenetelére. Ez alapján azt mondhatjuk, hogy a követelés összegétől függetlenül - egyéb szempontok alapján - lényegében bárhol meg lehetne húzni az alsó korlátot.

\subsection{ROC ANALÍZIS}

A kérdés most már csak az volt, hogy mi alapján döntse el a jogalkotó, hogy egy követelést FMH-s vagy peres úton enged-e érvényesíteni. Ezt nemcsak az ellentmondás valószínűségének, hanem egyéb tényezőknek is befolyásolniuk kell.

${ }^{63}$ Az új Pp. koncepcióját megalapozó előzetes vizsgálatok egyértelműen az utóbbit támogatták - lásd: REviCZKY-SZÉCSÉNYI-NAGY (2. lj.) 622.

${ }^{64}$ VARGA-ÉLESS (2. lj.) 802. 
Valójában annak kell lennie a fő szempontnak, hogy össztársadalmi szinten melyik a kedvezőbb, azaz költség-, idő-, emberi erőforrás- és eszköztakarékosabb megoldás. A két szélső lehetőség az, ha egyrészt - az érvényesített követelés összegétől függetlenül - minden esetben kötelezővé teszi a jogalkotó az FMH-t, a másik pedig, ha soha nem kötelező, vagy nem is létezik a jogintézmény a jogrendszerben. Az, hogy a két szélső megoldás között hol az optimum attól függ, hogy melyik igényérvényesítési útnak mennyi a társadalmi költsége és a haszna.

Az FMH minden olyan esetben - ugyan nem túl jelentős - többlet idő és fáradság a jogosultnak, amikor érdemi jogvita van a felek között, és a kötelezett úgyis ellentmond. Az FMH lehetőségének hiánya pedig tetemes felesleges idő és pénz a jogosultnak, a kötelezettnek és - utoljára, de nem utolsósorban - a bíróságokon keresztül az államnak is, amikor a felek között valójában nincs is jogvita, tehát egy FMH is jogerőre emelkedhetett és végrehajtható határozatot eredményezhetett volna. Ezeket a szükséges, különféle nemủ erőforrásokat - idő, pénz, emberi munkaerő stb. - nehéz pontosan számszerűsíteni és összesíthetővé tenni. A gyakorlati tapasztalatok alapján azt azonban biztosan kijelenthetjük, hogy egy bírósági per megindítása, azaz a keresetlevél megszerkesztése, beadása, annak bíróság részéről való feldolgozása, az esetleges hiánypótlás vagy a keresetlevél végzéssel történő visszautasítása, ${ }^{65}$ illetőleg a tárgyalás előkészítése, a felperes és az állam részéről többszörös ráfordítást igényel, mint egy FMH kibocsátása iránti kérelem benyújtása, az FMH kibocsátása, valamint az ellentmondás előterjesztése a jogosult, a közjegyző és a kötelezett részéről összesen.

Inkább tereljünk tehát számtalan ügyet feleslegesen az FMH irányába, amelyek azután ellentmondás előterjesztése miatt mégis perré alakulnak, minthogy bírósági útra engedjünk - az előbbiektől akár lényegesen kisebb számú - olyan ügyet, amely FMH-ként jogerőre emelkedett volna. A külön nemű „költségek” forintosíthatóságának és összesíthetőségének említett nehézsége miatt a helyes arányokat nem tudom megmondani. Úgy gondolom azonban, hogy a három vagy esetleg négy elterelt, de utóbb mégis perré alakult ügy FMH-s szakasza jelentette többlet - elsősorban idő - ráfordítás összesítve is kevesebb össztársadalmi „költség”, mint egyetlen per bíróságról való sikeres elterelésének - elsősorban állami költségráfordítás elmaradása formájában - jelentkező össztársadalmi haszna. Megerősíti ezt a kalkulációt az a tapasztalati tény is, hogy a korábbi alsó korlát értéke mellett FMH-s útra terelt, de ellentmondás folytán mégis perré alakult ügyek 30\%-át megszüntették a bíróságok még az első tárgyalás előtt. ${ }^{66} \mathrm{~A}$ ROC analízis eredményeinek értékelésénél, az alsó korlát, azaz a vágópont meghatározásánál tehát e szempontokat is szem előtt kellett tartani.

A fentieket a statisztika nyelvére lefordítva azt mondhatjuk, hogy a FP (a követelés összege alapján érdemi jogvita kialakulását sejtető, de FMH kibocsátása esetén mégis jogerőre emelkedő) esetek mennyiségét kell csökkenteni mindaddig, amíg számuk a FN (a követelés összege alapján érdemi jogvita hiányát ígérő, de FMH kibocsátása esetén mégis perré alakuló) ügyek számának egyharmadára, egynegyedé-

${ }^{65} \mathrm{Az}$ új Pp. perindítás című XII. fejezete szabályozza a peres eljárás e szakaszát.

${ }^{66}$ ReviczKY-SzÉcsÉNYI-NAgY (2. lj.) 620. 
re esik. A ROC analízis esetén szokásosan számolt mutatók mellett az adott esetben tehát figyelnünk kell a FN/FP arányra is: kívánatos, hogy ez az érték három-négy körül legyen. Ha így járunk el, akkor a FP esetek alacsony száma miatt várhatóan magas lesz a teszt PPV-je, azaz a követelés összege alapján a peres út irányába terelt igényérvényesítések találati aránya: amelyik igényt bíróság elé engedünk, az nagy valószínűséggel úgysem futott volna jogerőre FMH-ként.

A NPV viszont elkerülhetetlenül romlani fog a FN ügyek számának emelkedése miatt. De ez, az adott esetben nem fontos. A fentiek miatt ugyanis nem baj, ha viszonylag sok FMH irányába terelt ügy, amelyröl a követelés összege alapján azt gondoltuk, hogy úgyis jogerős FMH lesz belőle, ellentmondás miatt mégis perré alakul. Ennek ugyanakkor van felső korlátja. Mivel a cél a bíróságra érkező ügyek számának csökkentése, ezért a számunkra legfontosabb, hogy ez a szám minél nagyobb legyen. Ezt pedig úgy kapjuk meg, hogy az FMH-s útra kényszerített, és valóban jogerőre is emelkedő, tehát a bíróságokról sikeresen elterelt TN ügyek számából kivonjuk az ugyan FMH-s útra irányított, de ellentmondás folytán mégis a bíróságokon „landoló”, tehát végső soron eredménytelenül elterelni megkísérelt FN ügyek számát. A kettő különbsége (TN-FN) a nettó bírósági ügyforgalom csökkenés, amit a jogalkotó is maximalizálni kívánt. A FN-ügyek száma csak addig emelkedhet, amíg a TN és a FN ügyek számának különbsége eléri a maximumát. A ROC eredmények értékelésének bevett gyakorlatával szemben tehát az adott esetben nem a TN ügyek teszt alapján negatív ügyeken belüli relatív mennyiségét, a NPV-t, hanem a TN és az FN ügyek abszolút különbségét kell figyelnünk. A TN-FN művelet eredményeként kapott szám értékelésekor azonban figyelembe kell venni, hogy az elemzett ügyeknek csak 55,4\%-a potenciális FMH, azaz csak ennyi indult ténylegesen a bíróságon perként. A bírósági ügyszám csökkenés tehát valójában csak kb. fele lesz a mindenkori vágóponthoz tartozó TN-FN értéknek.

Nagyon magas lesz a teszt SPEC értéke, szinte minden érdemi jogvita nélküli, tehát FMH-s útra alkalmas ügyet azonosítani fogunk. Viszont a SEN értéke alacsony marad: az érdemi jogvitával terhelt ügyeknek viszonylag kis hányadát irányítjuk közvetlenül peres útra. De ez nem baj, mert kis időveszteség árán, ellentmondás folytán, úgyis perré alakulnak. A vágópont minden bizonnyal nem a SEN+SPEC összege szerinti optimum körül lesz. Mivel nem egy kis elemszámú mintát vizsgáltam, hanem egy teljes év érkezését dolgoztam fel, ezért az abszolút számok is informatívak, nem csak a kiszámolt mutatók és arányszámok.

Lássuk tehát ennek fényében a kapott eredményeket. Az AUC értéke alapján látható, hogy a korábbi vizsgálatok adataira alapozott várakozásoknak megfelelően az érvényesített követelés összege nem igazán megbízható klasszifikátora a magánjogi igényeknek a követelés mögött meghúzódó érdemi jogvita létét vagy hiányát illetően. A görbe ugyan erősen szignifikánsan, de nem túl nagy mértékben távolodik el az átlós egyenestől, és nem igazán közelíti meg az egységnégyzet bal felső sarkát. A klasszifikátor teljes alkalmatlanságára vonatkozó nullhipotézist a p értékére tekintettel elvetjük, de levonhatjuk a következtetést, hogy a követelés összege alapján nem lehet igazán megbízhatóan elkülöníteni az eljárás várható kimenetele szerint a magánjogi igényeket. 
A 4. számú táblázatban a ROC görbe döntés szempontjából releváns vagy más okból kiemelt jelentőségű, és a 4. számú diagramon is (a táblázat sorszámait követve) jelzett pontjainak koordináta-adatait és a hozzájuk tartozó tényleges esetszámokat, valamint az egyéb számított mutatók értékeit adom meg. Az egyes vágópontok kiemelését indokolttá tevő adatot mindig vastagon szedtem a 4. számú táblázatban.

A 4. számú táblázat és a 4. számú diagram alapján látható, hogy az alsó korlát változatlanul hagyása azt jelenti, hogy minden 1 millió forint vagy azt meghaladó követelés iránti ügyet peres útra érdemesnek tekintünk, de ez esetben 31 014-szer tévedünk, mert az FMH-k és a hipotetikus FMH-k közül összesen ennyi jogerőre emelkedik. Ez a görbe jobb felső pontja. A 4. számú táblázat második sora azt az esetet foglalja össze, ha a vágópontot 2000005 forintra emelnénk. Így lényegesen javulnak a teszt eredményei, mert a FP esetek száma 12 308-ra esik, tehát már ezzel a lépéssel 18706 ügyet elterelnénk a bíróságról, és ellentmondás folytán is csak 3533 alakulna utóbb perré.

\section{4. számú táblázat}

A várhatóan perré alakuló és a jogerőre emelkedő FMH-k követelés értéke szerinti ROC analízisének eredményei

\begin{tabular}{|c|c|c|c|c|c|c|c|c|c|c|c|c|}
\hline \multirow{2}{*}{ 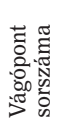 } & \multirow[t]{2}{*}{$\begin{array}{l}\text { Vágópont } \\
(\mathrm{Ft})\end{array}$} & \multicolumn{2}{|c|}{$\begin{array}{l}\text { ROC görbe } \\
\text { koordinátái }\end{array}$} & \multicolumn{4}{|c|}{$\begin{array}{c}\text { esetszámok } \\
\text { az egyes csoportokban }(\mathrm{db})\end{array}$} & \multicolumn{5}{|c|}{ számított mutatók } \\
\hline & & SEN & $\begin{array}{r}1- \\
\text { SPEC }\end{array}$ & $\mathrm{TP}$ & FP & FN & $\mathrm{TN}$ & PPV & PEC & $\begin{array}{c}\text { SEN+ } \\
\text { SPEC }\end{array}$ & FN/FP & TN-FN \\
\hline 1. & 0 & 1 & 1 & 170 & 310 & 0 & 0 & o & 0 & 1 & 0 & 0 \\
\hline 2. & 00005 & 732 & 0,397 & 637 & 12308 & 3533 & 18706 & 439 & 03 & 35 & 87 & 173 \\
\hline 3. & 2980223 & 0,601 & 0,230 & 7909 & 7141 & 5261 & 23873 & 26 &, 770 & 370 & 737 & 18 \\
\hline 4. & 3000233 & 0,585 & 0,221 & 7705 & 6840 & 5465 & 24174 & 0,530 & 0,779 & 1,364 & 0,799 & 18709 \\
\hline 5. & 4000369 & 0,488 & 0,149 & 6425 & 4607 & 6745 & 26407 & 0,582 & 0,851 & 1,339 & 1,464 & 19662 \\
\hline 6. & 5000001 & 0,403 & 0,102 & 5302 & 3177 & 7868 & 27837 & 0,625 & 0,898 & 1,300 & 2,477 & 19969 \\
\hline 7. & 5490578 & 0,376 & 0,088 & 4955 & 2738 & 8215 & 28276 & 0,644 & 0,912 & 1,288 & 3,000 & 20061 \\
\hline 8. & 5782573 & 0,362 & 0,081 & 4768 & 2527 & 8402 & 28487 & 0,654 & 0,919 & 1,281 & 3,325 & 20085 \\
\hline 9. & 6000421 & 0,343 & 0,075 & 4513 & 2336 & 8657 & 28678 & 0,659 & 0,925 & 1,267 & 3,706 & 20021 \\
\hline 10. & 6309702 & 0,331 & 0,071 & 4364 & 2201 & 8806 & 28813 & 0,665 & 0,929 & 1,260 & 4,001 & 20007 \\
\hline 11. & 7001045 & 0,303 & 0,060 & 3986 & 1875 & 9184 & 29139 & 0,680 & 0,940 & 1,242 & 4,898 & 19955 \\
\hline
\end{tabular}

A görbe következő kiemelt pontja (a 4. számú táblázat 3. sora) azért érdekes, mert ennél a 2980223 forintos vágópontnál maximális (1,370) a SEN+SPEC értéke, azaz, ha csak matematikai szempontokat nézünk, akkor ezt az értéket kellene alsó korlátnak választani. Vegyük észre, hogy ez a matematikailag optimális vágópont milyen közel van az új Pp.-ben a jogalkotó által választott 3 millió forintos alsó korláthoz (a 4. számú táblázat 4. sora). Az új Pp. indokolásának szükszavúsága miatt ugyan nem tudjuk, hogy ez csak a véletlen műve-e, vagy komoly számításokra alapul a jogalkotó döntése.

Látni kell azonban, hogy a jogalkotó által választotthoz közeli 3000233 forintos vágópont esetén ugyan már kétségtelenül 24174 ügyet terelünk el sikerrel a 
bíróságokról, de ebből le kell vonni a 5465 FN esetet, amelyek FMH-ból perré alakulnak. A tiszta „nyereség” tehát a bírósági ügyforgalomban 18 709-cel kevesebb per. De még így is lehetővé tesszük, hogy a felek 6840 olyan ügyben indíthassanak pert, amely FMH-ként jogerőre emelkedhetett volna. A FP esetek száma még mindig magas, meghaladja a FN esetek számát, tehát az FN/FP arány $(0,799)$ messze van az optimálisnak tekintett 34-töl.

A vágópontot 4000369 Ft-ra emelve érnénk el először azt, hogy a FN (ellentmondás miatt perré alakuló) ügyek száma meghaladja a FP, tehát a követelés értéke alapján valósnak vélt jogvita miatt tévesen peres útra terelt ügyek számát, de még mindig csak alig másfélszeresen (FN/FP=1,464). A TN-FN értéke tovább emelke$\operatorname{dik}(19662)$.

A kívánatosnak tartott FN/FP aránytól még akkor is messze lennénk, ha a vágópontot tovább emelve 5000001 forintban határoznánk meg azt. Figyelemre méltó ugyanakkor, hogy a SPEC értéke alapján a tényleges jogvitát nélkülöző ügyeknek már 89,8\%-át sikerrel azonosítjuk, és eltereljük a bíróságokról, és már csak 3177 FP ügy esetében hibázunk. A SEN+SPEC értéke ugyan csökkenni kezd (1,300), de ez még nem jelentős, és a fenitek szerint nem is olyan fontos szempont. A nettó bírósági ügyszám csökkenés, a TN-FN értéke tovább emelkedik (19 969).

További majdnem félmillió forinttal 5490578 forintra (a 4. számú táblázat 7. sora) kell emelnünk a vágópont értékét, hogy a minimálisan kívánatosnak tartott FN/FP arányt (3) elérjük. A következő, a táblázat 8. sorában kiemelt 5782573 forint összegű vágópont azért érdekes, mert a kiemelten fontos TP-FN érték itt éri el a maximumát, 20 085-öt. A bíróságokról ténylegesen elterelt ügyek száma tehát 1178-cal (20 085-18 907) több, mint a jogalkotó által választotthoz közeli 3000233 forintos vágópont esetén. A szintén jelentős FN/FP hányados is az optimális sávban van $(3,325)$. A számunkra fontos szempontok alapján tehát ez a vágópont tűnik az FMH optimális alsó korlátjának.

De a táblázat 9. és 10. sora alapján látszik, hogy egészen 6309702 forintig minden aggodalom nélkül eltolható a vágópont, mert a FN/FP arány csak ekkor éri el a 4-et, a SEN+SPEC értéke $(1,26)$ - a SPEC értékének dinamikus emelkedése $(0,929)$ következtében - még ekkor sem esik jelentősen a maximumhoz képest. Így már a tévesen bírósági útra engedett FP ügyek száma is 2201-re csökken.

Ha azonban tovább emeljük a vágópontot 7001045 forintra, akkor a bíróságról sikerrel elterelt TN ügyek és a végül mégis perré alakult FN ügyek különbsége, azaz a nettó bírósági ügyérkezési nyereség már 19 955-re csökken, a FN/FP arány $(4,898)$ sem optimális már, és SEN+SPEC értéke is 1,242-re esik. Minden lényeges mutató romlik tehát. Minden szempontot figyelembe véve tehát az FMH alsó korlátjának értékét a 7. és a 10. sorszámmal jelölt vágópont, azaz 5490578 és 6309702 forint közötti tartományban kellett volna vagy kellene meghatározni. 
A fentieket összefoglalva tehát megállapíthatjuk, hogy a jogalkotó által kitűzött cél, a perek számának csökkentésére alkalmas eszköz lehet a jogviták FMH irányába terelése a peresíthető követelések minimális összegének megszabásával. Pusztán a követelés összege alapján azonban nem lehet egyértelmüen meghatározni az alsó korlát helyes összegét, mert az nagyon gyenge kapcsolatban áll az eljárás kimenetelével, azaz nem kielégítő megbízhatóságú klasszifikátor. Akárhol húzzuk is meg tehát a követelés összege segítségével a vágópontot és ezzel az alsó korlát összegét, mindenképpen sok lesz az érdemi jogvita léte vagy hiánya szempontjából tévesen besorolt és ezért nem az adekvát jogérvényesítési út irányába terelt ügy. Az alsó korlát meghatározása során ezért egyéb szempontokat, így különösen a jogalkotó által is értékelt bírósági ügyforgalmi adatokra gyakorolt hatást is figyelembe kell venni. Azt kell továbbá szem előtt tartani, hogy összességében mi a legjobb: hány ügyet kényszeríthetünk feleslegesen FMH irányába úgy, hogy ennek össztársadalmi plusz „költsége” kevesebb legyen, mint a bíróságról sikerrel elterelt ügyeken elért össztársadalmi nyereség. Ennek kiszámítása kétségtelenül nehéz, de ha ezt figyelembe véve az indokolatlanul FMH igénybevételére kényszerített (FN), illetve szükségtelenül bírósági útra engedett ügyek (FP) helyes aránya az általam kijelölt 3-4 közötti sávon kívül esik, akkor az optimális vágópont a fenti elvek, a 2018. évi alsó korlát emelés tapasztalatai, illetőleg friss ügyforgalmi adatok alapján könynyen újra kalkulálható.

Jelenlegi tudásunk birtokában azonban annyit bizonyosan kijelenthetünk, hogy - az általa elérni kívánt cél szempontjából - helyesen járt el a jogalkotó, amikor az évszázados hagyományokkal szakítva feladta az FMH alsó korlátjának értékállandóságát, és annak összegét - azt tisztán jogpolitikai eszközként kezelve - elkezdte a magánjogi igények állami úton való érvényesítésének a XXI. századi követelményeknek megfelelő, személyes közreműködést nem igénylő, gyors, költségtakarékos és elektronizált FMH-s eljárás irányába terelésére használni. Az általa meghatározott értékhatár matematikai szempontból helyes, de - ügyforgalmi, pénzügyi szempontokat és az eljárásjogi tapasztalatokat is figyelembe véve - a jelentősebb hatás érdekében bátrabb is lehetett volna és - az új Pp. Koncepciójának alapját képező tanulmányban írtakat legalább részben akceptálva - akár az 5500 0006500000 forintos sávba is emelhette volna azt. Vagy - az általam végzett elemzést a Jat. 21. §-a szerinti utólagos hatásvizsgálatnak tekintve és eredményeit felhasználva - akár emelhetné ma is... 